\title{
Heterotrimeric G-protein a subunit (LeGPA1) confers cold stress tolerance to processing tomato plants (Lycopersicon esculentum Mill)
}

Xinyong Guo ${ }^{\dagger}$, Juju Li๋ ${ }^{\dagger}$ Li Zhang ${ }^{\dagger}$, Zhanwen Zhang, Ping He, Wenwen Wang, Mei Wang, Aiying Wang and Jianbo Zhu* (iD

\begin{abstract}
Background: Tomatoes (Lycopersicon esculentum Mill) are key foods, and their molecular biology and evolution have been well described. Tomato plants originated in the tropics and, thus, are cold sensitive.

Results: Here, we generated LeGPA1 overexpressing and RNA-interference (RNAi) transgenic tomato plants, which we then used to investigate the function of LeGPA1 in response to cold stress. Functional LeGPA1 was detected at the plasma membrane, and endogenous LeGPA1 was highly expressed in the roots and leaves. Cold treatment positively induced the expression of LeGPA1. Overexpression of LeGPA1 conferred tolerance to cold conditions and regulated the expression of genes related to the INDUCER OF CBF EXPRESSION-C-REPEAT-BINDING FACTOR (ICECBF) pathway in tomato plants. In the LeGPA1-overexpressing transgenic plants, the superoxide dismutase, peroxidase, and catalase activities and soluble sugar and proline contents were increased, and the production of reactive oxygen species and membrane lipid peroxidation decreased under cold stress.

Conclusions: Our findings suggest that improvements in antioxidant systems can help plants cope with the oxidative damage caused by cold stress, thereby stabilizing cell membrane structures and increasing the rate of photosynthesis. The data presented here provide evidence for the key role of LeGPA1 in mediating cold signal transduction in plant cells. These findings extend our knowledge of the roles of G-proteins in plants and help to clarify the mechanisms through which growth and development are regulated in processing tomato plants.
\end{abstract}

Keywords: Lycopersicon esculentum, LeGPA1, Cold tolerance, Overexpression, RNA interference, Antioxidants

\section{Background}

Abiotic stresses, such as drought, high temperature, chilling injury, salt injury, and heavy metal toxicity, seriously affect crop growth and food production, resulting in annual losses to agricultural production exceeding $\$ 100$ billion [1]. To resist injury, plants have evolved physiological pathways for

\footnotetext{
* Correspondence: jianboz9@sina.com

${ }^{\dagger}$ Xinyong Guo, Juju Li and Li Zhang these authors contributed equally and are co-first authors.

College of Life Science, Shihezi University, Shihezi 832000, China
}

sensing and transmitting transcriptional regulation and responses to low-temperature stress during long-term changes in the natural geographical environment. These include the transmembrane signal transduction pathways, in which signaling components on the cytoplasmic membrane, such as heterotrimeric G-proteins, play a crucial role [2, 3].

Heterotrimeric G-proteins are composed of a complex of three subunits, including $G \alpha, G \beta$, and $G \gamma$. The function of G-proteins is well understood in animals [4], and more than 20 species of $G \alpha$ have been identified in

(c) The Author(s). 2020 Open Access This article is licensed under a Creative Commons Attribution 4.0 International License, which permits use, sharing, adaptation, distribution and reproduction in any medium or format, as long as you give appropriate credit to the original author(s) and the source, provide a link to the Creative Commons licence, and indicate if changes were made. The images or other third party material in this article are included in the article's Creative Commons licence, unless indicated otherwise in a credit line to the material. If material is not included in the article's Creative Commons licence and your intended use is not permitted by statutory regulation or exceeds the permitted use, you will need to obtain permission directly from the copyright holder. To view a copy of this licence, visit http://creativecommons.org/licenses/by/4.0/ The Creative Commons Public Domain Dedication waiver (http://creativecommons.org/publicdomain/zero/1.0/) applies to the data made available in this article, unless otherwise stated in a credit line to the data. 
mammals. The $\mathrm{G \alpha}$ subunits have the following functional sites: ADP-ribosylation, GTP/GDP binding, plasma membrane receptor recognition and binding, GTPase activity, and intracellular effector binding sites. These sites are closely related to heterotrimeric Gprotein functions, and thus, $\mathrm{G} \alpha$ is generally considered to be a functional subunit [5]. Ma et al. used modern molecular biology techniques based on mammalian Gprotein $\alpha$-subunit sequence homologs to isolate the first GPA1 gene from Arabidopsis thaliana. The protein encoded by the gene has $36 \%$ similarity to the mammalian $\mathrm{G \alpha}$ subunit and contains conserved GTP-binding regions $[6,7]$. Subsequently, the cDNA sequence of the G-protein $\alpha$ subunit has been isolated in rice $[8,9]$, wild oat [10], tomato [11], soybean [12, 13], pea [14], spinach [15], and lotus [16]. The predicted amino acid sequences of all the proteins encoded by these cDNAs are similar to the functional domains identified on the mammalian $\alpha$ subunit, suggesting that GPA1 is a conserved gene ubiquitous to flowering plants. Furthermore, a single copy of GPA1 occurs in plants, indicating the gene likely has a non-redundant function in plant cells.

Heterotrimeric G-proteins are involved in several growth and development processes in plants. For example, overexpression of GPA1 can increase the sensitivity of Arabidopsis to gibberellin, resulting in increased response to gibberellin during seed germination [17-19], which further affects germination. $G \alpha$ can affect root development and positively regulate the growth and development of lateral roots [20]. At the same time, $\mathrm{G} \alpha$ can control the growth and development of the hypocotyl of seedlings by regulating cell differentiation [21,22]. Compared with Arabidopsis, Go-coding-gene deletion mutants of rice had a wider and darker leaf color phenotype and shorter plant size $[23,24]$. Studies have shown that the number of cells in $d l-l$ mutants is decreased [25]. Therefore, G $\alpha$ plays a positive regulatory role in rice cell differentiation.

Heterotrimeric G-proteins are also key signal transduction regulators in plants, controlling pathways related to abiotic stress [26]. In Arabidopsis, GPA1 is involved in oxidative stress signal transduction and can positively regulate the abiotic stress factors upstream of reactive oxygen species (ROS) and nicotinamide adenine dinucleotide phosphate (NADPH) [27]. Arabidopsis $\mathrm{G} \alpha$ subunit mutations reduced the sensitivity of the plant to ozone stress [28]. In pea (Pisum sativum Linn.), constitutive overexpression of $\mathrm{G} \alpha$ subunits enhanced transgenic pea resistance to salt stress [29]. Studies by Ferrero-serrano and Assmann have shown that under drought stress, the $d 1$ mutant $\mathrm{G \alpha}$ subunit of rice has a lower leaf temperature than the wild type and, thus, stronger resistance to drought stress [30]. Chakraborty et al., in their work on a group of Arabidopsis Ga subunit mutants, have reported that abiotic-stress-related gene expression is altered, suggesting that GAP1 is involved in Arabidopsis responses to heat and cold stress $[31,32]$. The expression of rice $\mathrm{G} \alpha, \mathrm{G} \beta$, and $\mathrm{G} \gamma$ subunits was also strongly induced by cold stress, which suggests these subunits have an active regulatory role in cold stress resistance in rice [33, 34]. Studies by Ma et al.

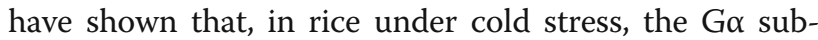
unit RGA1 (Rice G protein $\alpha$ subunit 1) interacts with CHILLING TOLERANCE DIVERGENCE 1 (COLD1) on the plasma membrane and endoplasmic reticulum, activating $\mathrm{Ca}^{2+}$ channels and enhancing resistance to low temperatures [35].

The processing tomato (Lycopersicon esculentum Mill.) was first grown in subtropical and tropical regions, but is now cultivated worldwide. These tomato plants are highly susceptible to cold stress, which thus has the potential to inflict substantial economic damage [36]. Therefore, identifying key genes for low-temperature tolerance is of great theoretical and practical significance.

To reveal the mechanisms behind the molecular regulation of low-temperature tolerance in tomato plants and to cultivate new low-temperature tolerant varieties, the GPA1 gene was cloned from processing tomatoes. Using a transgenic approach, we constructed overexpression and RNA-interference vectors for the LeGPA1 gene and studied the roles of LeGPA1 in plant growth and development and the low-temperature response. This study led to the genetic engineering of a novel series of low-temperature tolerant tomato plants. These low-temperature tolerant plants are now a valuable asset in the efforts to reveal the molecular regulation mechanisms of low-temperature resistance in processing tomato plants.

\section{Results}

\section{Bioinformatics analysis of LeGPA1}

Using cDNA from processing tomato leaves as a template and gene specific primers, we amplified the LeGPA1 gene (1176 bp) by PCR. The LeGPA1 gene encodes 392 amino acids. DNAMAN software was used to compare LeGPA1 and other plant GPA1 protein amino acid sequences. We found that the LeGPA1 protein from processing tomato had the highest similarity (98.72\%) with the amino acid sequence of the common tomato (Solanum lycopersicum) (Fig. 1a). Only single amino acid point mutations were detected, and there are no insertions or deletions. Phylogenetic trees of the LeGPA1 sequences from 13 species were established by ClustalX 2 and MEGA 4.1 software. We found that the LeGPA1 of processing tomato and SlGPA1 of the common tomato are on the same phylogenetic branch, and therefore, are closely related (Fig. 1b). The Conserved Domains tool of NCBI was used to analyze the conserved domains of sequences encoded 
A

LEGPA1 MLSVVFENMGSLCSRNKHYSQADDEENTQTAEIERRIEQETKVEKHTQKLLLLGAGGSGKSTIFKQIKLLFQTGFDEGE S1GPA1 MLSVVFENMGSLCSRNKHYSQADDEENTQTAEIERRIEQETKAEKHTQKLLLLGAGDSGKSTIFKQIKLLFQTGFDEEE ScGPA1 MLSVYFENMGSLCSRNKHYSQADDEENTQTAE IERRIEQETKADKHIQKLLLLGAGDSGKSTIFKQIKLLFQTGFDHAE SpGPA1 MLSVVFENMGSLCSRNKHYSQADDEENTQTAEIERRIEQETKADKHIQKLLLLGAGDSGKSTIFKQIKLLFQTGFDHAE StGPA1 MLSVVLENMGSLCSRNKHYSQADDEENTQTAE IERRIEQETKADKHIQKLLLLGAGDSGKSTIFKQIKLLFQTGFDEAE Consensumlsvv enmgslcsrnkhysqaddeentqtaeierrieqetka khiqkllllgag sgkstifkqikllfatgfde e

LeGPA1 LKNYIPVIHANVYQTITILHDGSKELAQNELEASKYLLSAENKEIGEKLSEIGGRLDYPHLTKDLVQDIEALWKDPAIQ S1GPA1 LKNYIPVIHANVYQTTKILHDGSKELAQNELEASKYLL SAENKEIGEKLSETGGRLDYPHLTKDLVQDIEALWKDPAIO ScGPA1 LKNYIPVIHANVYQTTKILHDGSKELAQNELEASKYLLSTENKEIGEKLSETGGRLDYPHLTKDLVQDIEALWKDPAIQ SpGPA1 LKNYIPVIHANYYQTTKILHDGSKELAQNELEASKYLLSAENKEIGEKLSETGGRLDYPHLTKDLVQDIEALWKDPATQ StGPA1 LKNYIPVIHANVYQTIKILHDGSKEL A NELFASKYLL AAENKEIGEKLSETGGRLDYPRL TKDLVQDIEALWKDPAIO Consensudknyipvihanvyqt kilhdgskelaqneleaskylls enkeigeklseiggrldyp 1tkdlvqdiealwkdpaiq

LEGPA1 ETLLRGNELQVPDCAHYFMENLERFSDVHYIPTKEDVLFARIRTTGVVEIQFSPVGENKKSGEVYRLFDVGGQRNVRRK SIGPA1 ETLLRGNELQVPDCAHYFMENLERFSDVHY IPTKEDVLFARIRTTGVVEIQFSPVGENKKSGEVYRLFDVGGQRNERRK SCGPA1 BTL SPGPA1 ETLLRGNLQVDCAHYNENLER SLVHYPTKEDLFARTRTGVEIQFSPGENKSGEVYRLFDVGGQRNERRK STGP

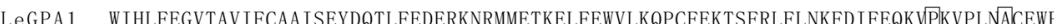
LEGPA1 WIHLFGNAVIFA SIGPA1 WIHLFEGVAVIFCAAISEYDQTLFEDERKNRMMETKELFEWVLKQPCFEKTSFMLFLNKFDIFEQKVPKVPLNACEWF SCGPA1 WILLEVTAVECAAISEYDQTLFEDERKNRMMETKELFEWVLKQPCFEKTSHMLFLNKFDIFEQKYPKVPLNACEWF StGPA1 WIHLFEGVTAVIFCAAISEYDQTLFEDERKNRMMETKELFEWVLKQPCFEKTSFMLFLNKFDIFEQKVLKVPLNTCEWF Consensusihlfegvtavifcaai seydqt lfederknrmmetkelfewvlkqpcfektsf $1 \mathrm{flnkfdifeqkv} \mathrm{kvpln} \mathrm{cewf}$

LEGPA1 KDYQSVSTGKQEIEHAYEFVKKKFEESYFQCTAPDRVDRVFKIYRTTALDQKLVKKTFKLVDETLRRRNLFEAGL S1GPA1 KDYQSVSTGKQEIFHAYEFVKKKFEESYFQCTAPDRVDRVFKIYRTTALDQKLVKKTFKLVDETLRRRNLFEAGL SCGPA1 KDYQSVSTGKQEIEHAYEFVKKKFEESYFQCTAPDRVDRVFKIYRTTALDQKLVKKTFKLVDETLRRRNLFEAGL SpGPA1 KDYQSVSTGKQEIEHAYEFVKKKFEESYFQCTAPDCVDRVFKIYRTTALDQKLVKKTFKLVDETLRRRNLFEAGL StGPA1 KDYQSVSTGKQEIEHAYEFVKKKFEESYFQCTAPDCVDRVFKIYRTTALDQKLVKKTFKLVDETLRRRNLFEAGL
Consensukdyqsvstgkqeiehayefvkkkfeesyfqctapd vdrvfkiyrttaldqklvkktfklvdet1rrrnlfeagl

$\mathrm{B}$
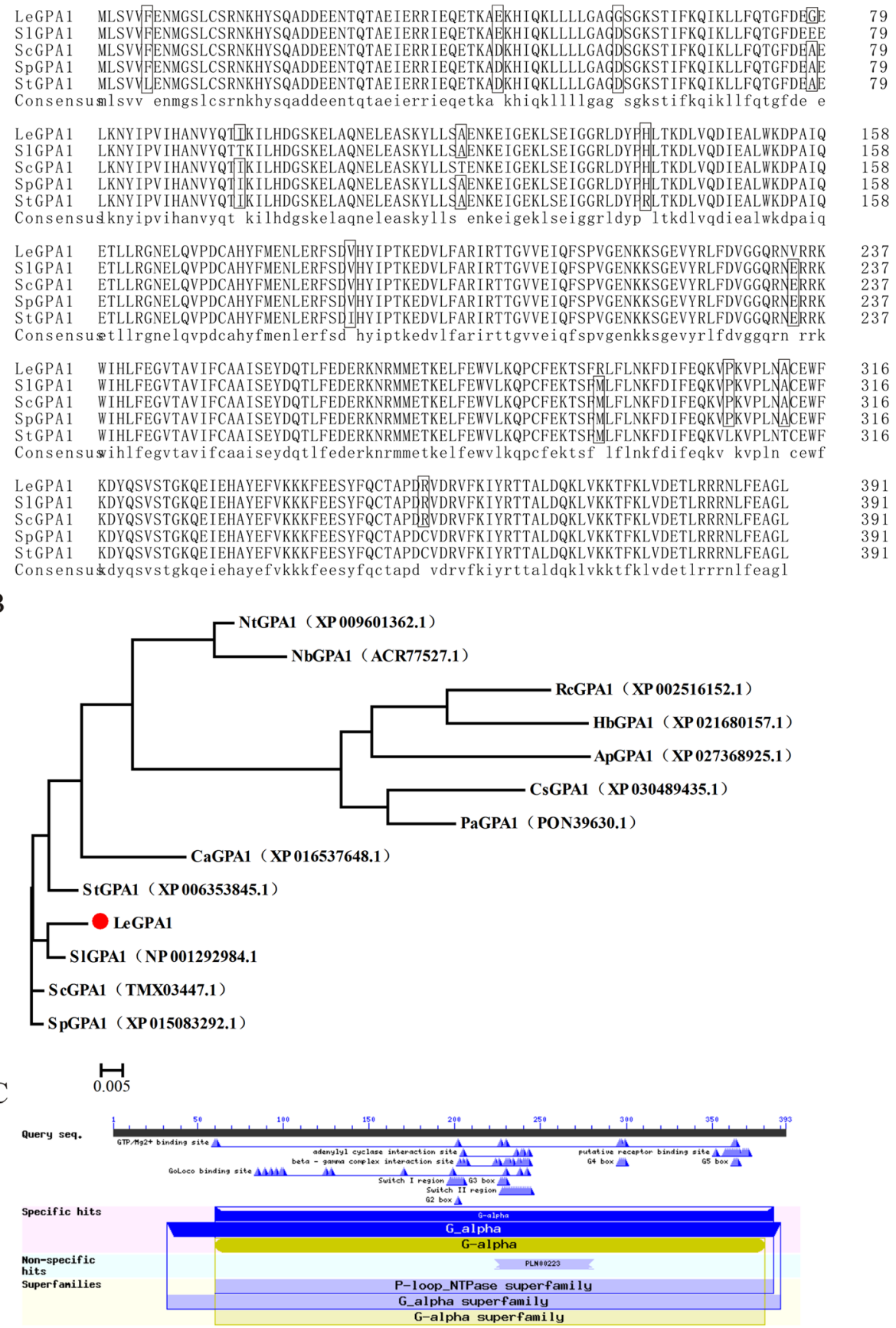

Fig. 1 Lycopersicon esculentum LeGPA1 sequence analysis. a LeGPA1 amino acid sequence alignment with other plant species. b Phylogenetic relationship between LeGPA1 protein and GPA1 proteins from other plant species. MEGA 5.1 was used for phylogenetic tree construction, with protein sequences used for such construction being from GenBank as follows: Nicotiana tomentosiformis (XP_009601362.1); Nicotiana benthamiana (ACR77527.1); Ricinus communis (XP_002516152.1); Hevea brasiliensis (XP_021680157.1); Abrus precatorius (XP_027368925.1); Cannabis sativa (XP_030489435.1); Trema orientale (PON39630.1); Capsicum annuum (XP_016537648.1); Solanum tuberosum (NP_001275141.1); Solanum lycopersicum (NP_001292984.1); Solanum chilense (TMX03447.1); and Solanum pennellii (XP_015083292.1). Bootstrap replicate values (1000X) were obtained. c Prediction of the conserved domain of LeGPA1

by the LeGPA1 gene. The protein encoded by this gene has a guanine nucleotide-binding protein subunit alpha domain, which belongs to the G-alpha family (Fig. 1c).

\section{Subcellular localization of LeGPA1}

To determine the location of LeGPA1 in cells, the LeGPA1 gene was cloned into a pCAMBIA2300-35SGFP (green fluorescent protein) vector downstream of 
the 35S promoter and upstream of the GFP gene. The fusion protein expression vector p35S-LeGPA1GFP constitutively expressed LeGPA1-GFP (Fig. 2a). The plasmids were extracted, and p35S-LeGPA1-GFP and pm-rk (cell membrane marker) were transformed into Arabidopsis protoplasts. By this approach, LeGPA1 was found to localize to the cell membrane (Fig. 2b).

\section{Expression analysis of LeGPA1 in processing tomato}

By quantitative reverse transcription PCR (qRT-PCR), we analyzed the LeGPA1 expression patterns in the various organs of wild-type processing tomato. Detectable LeGPA1 expression was found in all examined organs, with maximal expression in roots, then leaves, and fruits, and the lowest expression in stems (Fig. 3a). To further verify whether the expression of LeGPA1 is induced by stress, we also measured LeGPA1 expression under different stress treatments. As shown in Fig. 3b, the low-temperature treatment rapidly induced the upregulation of LeGPA1 gene within $3 \mathrm{~h}$ by 8.01 times. Then the gene expression level slowly decreased to 7.69 times of that before the treatment during the next $3 \mathrm{~h}$, while reaching the peak value at $9 \mathrm{~h}$ treatment (9.63 times higher). These indicate that low-temperature treatment could upregulate LeGPA1 gene expression. When treated with $20 \%$ PEG-6000, the alteration of gene expression during the first $6 \mathrm{~h}$ was very slow. Whereas, at 9 and 12 $\mathrm{h}$, the expressions of LeGPA1 were 4.14 and 4.38 (maximum) times than that before treatment, respectively, followed by a slow decrease at $24 \mathrm{~h}$ and then a rapid decrease afterwards (Fig. 3c). The treatment of $200 \mathrm{~mm} \mathrm{NaCl}$ upregulated the expression level of LeGPA1, with the maximum effect achieved at $9 \mathrm{~h}$ (4.84 times higher) and a rapid decrease for level-off after $12 \mathrm{~h}$ (Fig. 3d). Based on these results, we concluded that LeGPA1 could be induced by a variety of stresses.

\section{Identification of transgenic processing tomatoes}

To evaluate the importance of LeGPA1 in the lowtemperature stress response of processing tomato, we used an Agrobacterium-mediated method to generate transgenic plants (LeGPA1-overexpressing and gene silencing) (Fig. S1). Regenerated plants were obtained and tested by PCR. Three LeGPA1-overexpressing transgenic lines from positive plants $(\mathrm{OE}-1 / 2 / 3)$ and three RNA-interfering transgenic lines (RI-1/2/3) were selected and used for qRT-PCR detection (Fig. 4). Relative LeGPA mRNA levels in OE-1, OE-2, and OE3 plants increased 4.12-, 6.13-, and 7.69-times, respectively, compared with wild-type plants, and LeGPA mRNA levels in RI-1, RI-2, and RI-3 decreased by 0.90-, 0.78-, and 0.74-times, respectively. Therefore, based on the results of gene expression analysis, we selected two overexpression lines (OE-2, OE-3) and two RNA-interfering lines (RI-1, RI-2) for further research on cold-resistance function.

\section{Analysis of biological characteristics of transgenic tomato} We tested a panel of biological indicators (plant height, stem thickness, root length, and root fresh weight) among 80-day-old plants, comparing the wild-type and transgenic tomatoes. As shown in Fig. 5, We found that the LeGPA1-overexpressing transgenic tomato plants grew significantly taller compared with wild-type controls, by $4-11.6 \%$. However, the plant growth of RNA interference lines was lower than that of wild-type tomatoes, by 28.9$36.9 \%$. Root length or fresh weight were comparable in wild-type and transgenic plants. In contrast, the stem thickness of the LeGPA1-overexpressing transgenic plants increased by $13.5-18.3 \%$ compared with wild-type plants, while the stem thickness of the RNA-interference transgenic plants was significantly increased (by 34.1-37.4\%) compared with wild-type controls $(P<0.01)$.

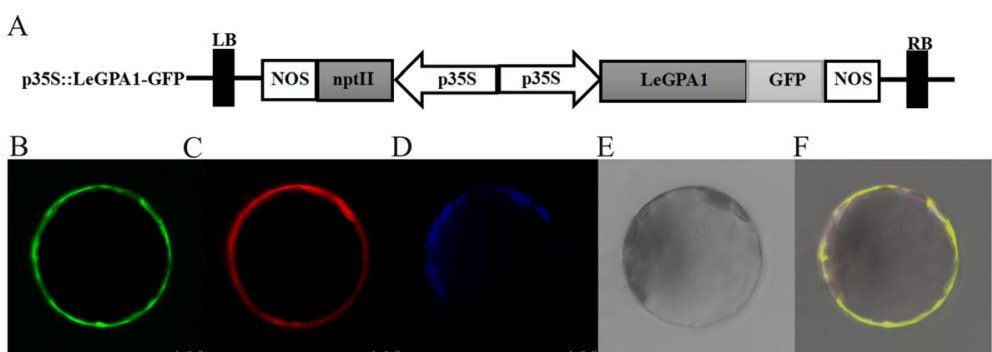

Fig. 2 LeGPA1 localization within cells. Arabidopsis mesophyll protoplasts were co-transformed with p35S-LeGPA1-GFP and a plasma membrane marker PM-rk. We co-transformed Arabidopsis mesophyll protoplasts using p35S-LeGPA1-GFP and the PM-rk plasma membrane marker. a The p35S-LeGPA1-GFP plasmid. b Arabidopsis mesophyll protoplasts following LeGPA1-GFP fusion protein expression. c Arabidopsis mesophyll protoplasts following Pm-rk expression. d Chloroplasts within Arabidopsis protoplasts. e A bright-field image of Arabidopsis mesophyll protoplasts. f Merged fluorescent images collected from LeGPA1-GFP and PM-rk expressing protoplasts. Scale bars $=7.5 \mu \mathrm{m}$ 

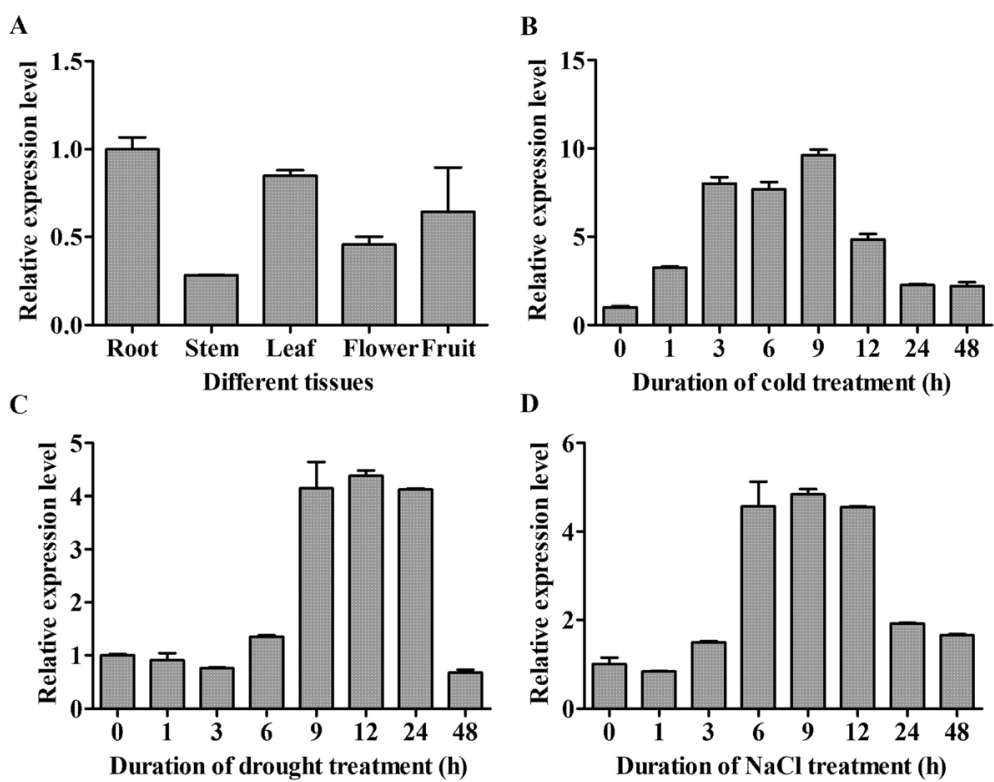

Fig. 3 Assessment of LeGPA1 mRNA expression in wild-type plants. a LeGPA1 expression was evaluated in the fruits, stems, leaves, flowers, and roots of L. esculentum following growth at $25^{\circ} \mathrm{C}$. $\mathbf{b}$ LeGPA1 gene expression was evaluated after $0,1,3,6,9,12,24$, and $48 \mathrm{~h}$ at $4{ }^{\circ} \mathrm{C}$ in the leaves of these plants. c Expression of the LeGPA1 gene in L. esculentum leaves following drought stress generated using 20\% PEG-6000 for 0, 1, 3, 6, 9, 12, 24, and $48 \mathrm{~h}$. $\mathbf{d}$ Expression of LeGPA1 gene in leaves of L. esculentum treated with salt stress generated using $200 \mathrm{mM} \mathrm{NaCl}$ for $0,1,3,6,9,12$, 24, and $48 \mathrm{~h}$. Reported data are derived from triplicate analyses

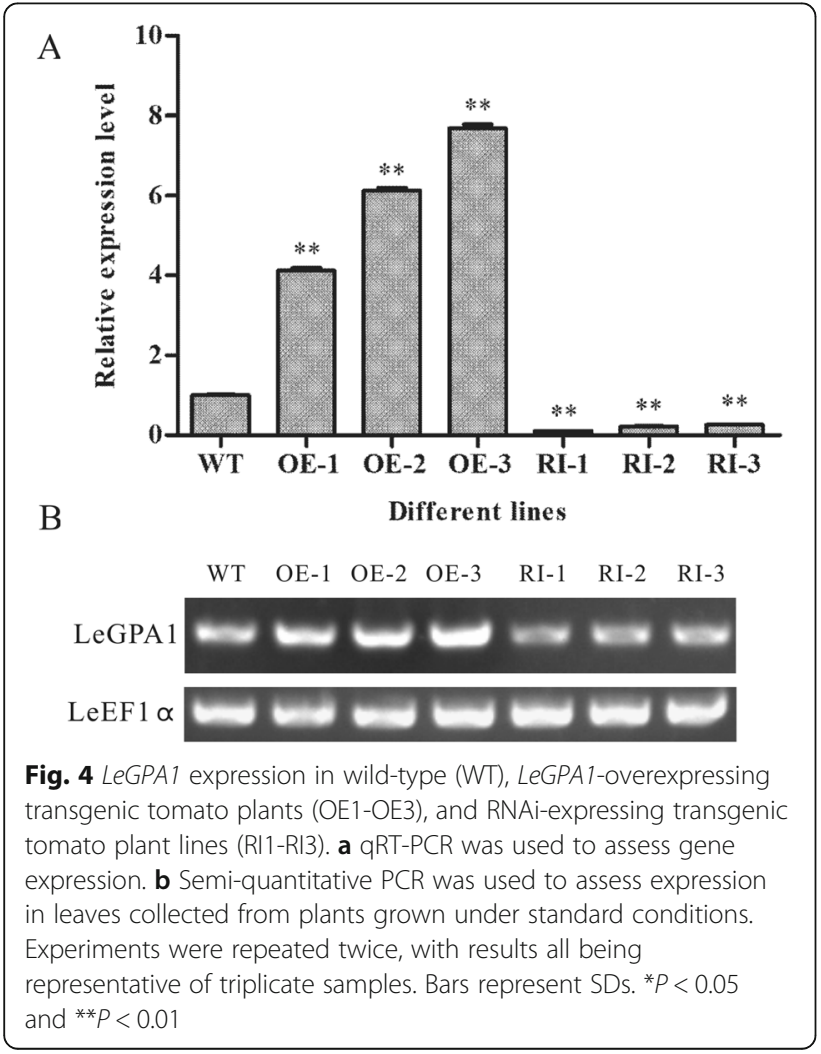

\section{Overexpression of the LeGPA1 gene enhanced the resistance of transgenic tomato seedlings to low temperature}

To test the cold stress tolerance of the transgenic tomato plants, T2-generation seeds of LeGPA1-overexpressing transgenic plants, RNA-interference transgenic plants, and wild-type processing plants were uniformly seeded into rectangular pots. The plants were grown under normal conditions $\left(25^{\circ} \mathrm{C}\right)$ for 3 weeks and then transferred to a $4{ }^{\circ} \mathrm{C}$ incubator for 7 days. Phenotypes were observed, and seedling fresh weight and survival were measured at $0,3,5$, and 7 days at low temperature. As shown in Fig. 6a, both wild-type and transgenic plants grew normally at $4{ }^{\circ} \mathrm{C}$. After 3 days of $4{ }^{\circ} \mathrm{C}$ treatment, RNA interference tomato seedlings began to show signs of wilting (slight curving of plant parts was seen). Wild-type tomato seedlings were slightly wilted but not as much as the RNA-interference lines, while the LeGPA1-overexpressing tomato plant seedlings showed better growth than the RNA-interference seedlings. After 5 days at low temperature, most of the RNA interference tomato seedlings had bent and fallen, the wild-type processing plants began to have curved tops that inhibited growth, and some of the LeGPA1-overexpressing lines also showed wilting. After 7 days of treatment, the RNAinterference seedlings had almost all perished, with only a few surviving; there were few surviving wild-type processing seedlings but more than the surviving RNA- 
A

B

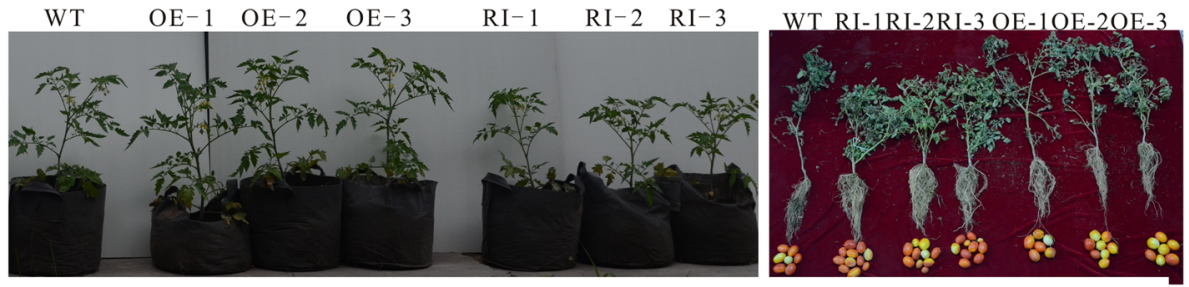

C

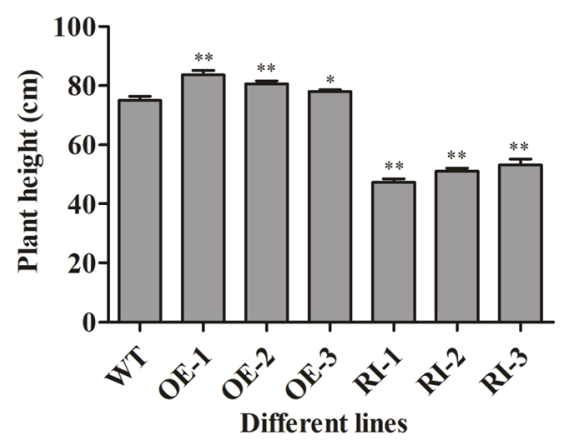

D

$\mathrm{E}$

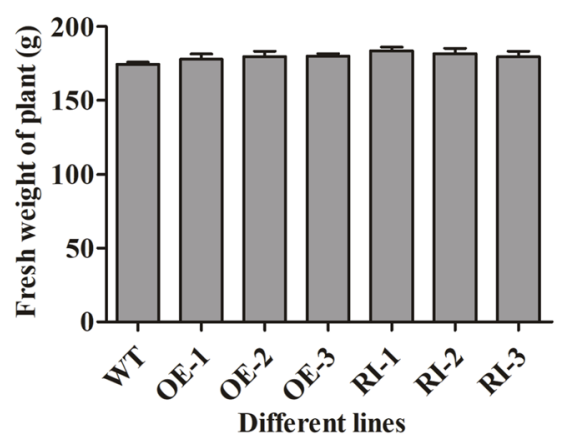

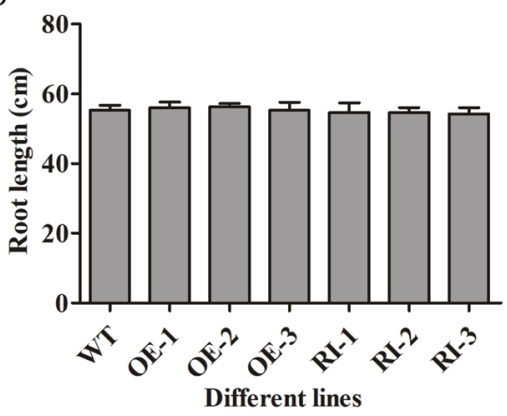

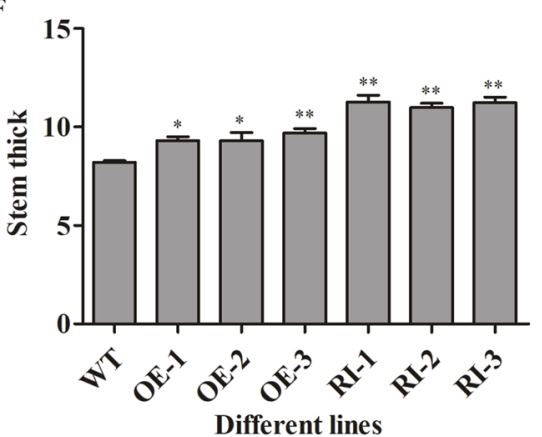

Fig. 5 Assessment of the characteristics of wild-type and transgenic plants. a The growth of wild-type plants and transgenic plants expressing the LeGPA1 gene in the field. b Plant fruiting. c Plant height. $\mathbf{d}$ Root length. e Plant fresh weight. $\mathbf{f}$ Stem thick. Data are the means and SDs from triplicate samples. ${ }^{*} P<0.05$ and ${ }^{*} P<0.01$ vs. WT.

interference lines, while the LeGPA1 transgenic seedlings had only undergone partial wilting. After 7 days of lowtemperature treatment, the tomato seedlings were placed in a 4 to $25^{\circ} \mathrm{C}$ incubator for 3 days under normal conditions to recover. It was found that almost all the RNAinterference tomato seedlings had died, a few wild-type plants survived, and a few LeGPA1-overexpressing plants had died. Fresh weight measurements and survival statistics were also performed, and similar results were obtained. Following 7 days of cold treatment, the fresh weight of the LeGPA1-overexpressing lines had decreased by $43.4 \%(\mathrm{OE}-2)$ and $39.6 \%(\mathrm{OE}-3)$, that of the wild-type plants had decreased by $68.5 \%$, and that of the RNA-interference lines had decreased by $70.7 \%$ (RI-1) and $70.1 \%$ (RI-2), relative to the values taken before treatment (Fig. 6b). Following a 7-day low-temperature treatment period, both transgenic and wild-type seedlings exhibited significantly decreased survival. However, the survival rate of the LeGPA1-overexpressing plants was increased significantly compared with the RNA-interference plants and wild-type controls, and the wild-type controls had higher survival rates compared with RNA-interfered plants (Fig. 6c). These data show that overexpression of LeGPA1 increased transgenic tomato seedling resistance to low temperatures.

\section{Growth analysis of transgenic tomato sprouts under low- temperature stress}

To further assess transgenic tomato low-temperature resistance, transgenic and wild-type plants were next grown for 6 weeks under standard conditions before being transferred for 5 days to $4^{\circ} \mathrm{C}$. Normal growth in wild-type and transgenic plants was observed at room temperature. Following growth at $4{ }^{\circ} \mathrm{C}$, the wild-type 


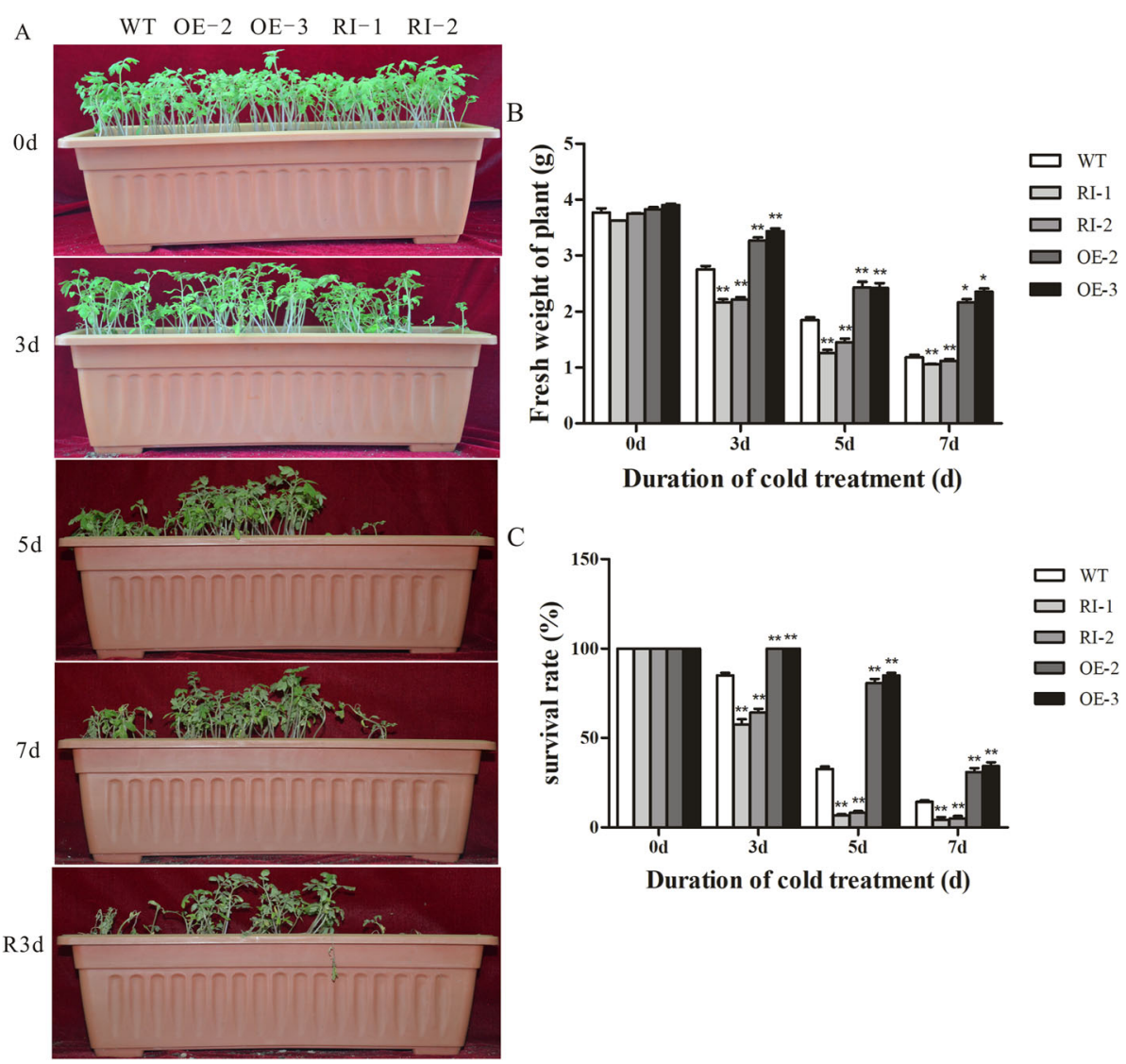

Fig. 6 Assessment of young wild-type (WT) and transgenic tomato plant cold resistance. a Phenotypes of untreated 3-week-old WT and transgenic tomato plants or those treated with cold stress for $5 \mathrm{~d}$. b Fresh weight. c Survival rate. Data are the means and SDs from triplicate samples. ${ }^{*} \mathrm{P}<0.05$ and ${ }^{*} \mathrm{P}<0.01$

tomato leaves had wilted to different degrees, while all the RNAi tomato leaves had wilted and drooped, were dark brown with water stains on the surface, and some of the leaves had died. However, there was almost no change to the LeGPA1-overexpressing tomatoes, which grew normally (Fig. 7). This indicates that LeGPA1 is an important mediator of low-temperature resistance within these processing tomatoes.

\section{Overexpression of LeGPA1 alleviates cell membrane} damage under low-temperature stress

Malondialdehyde (MDA) is a ROS-associated lipid peroxidation byproduct. Cell membrane permeability can be gauged based on MDA levels, as well as relative electrolyte leakage (REL). Under low-temperature stress, the MDA and REL levels of both wild-type and transgenic plants rapidly increased (Fig. 8a, b). The MDA and REL levels of

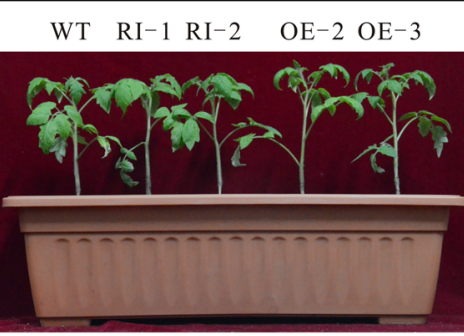

$25^{\circ} \mathrm{C}$

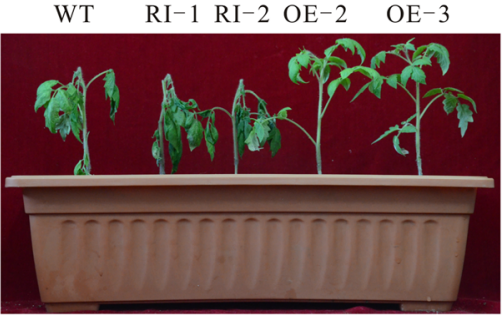

$4^{\circ} \mathrm{C}$

Fig. 7 The growth of 6-week-old WT and transgenic plants for 0 or 5 days under $4{ }^{\circ} \mathrm{C}$ 
A

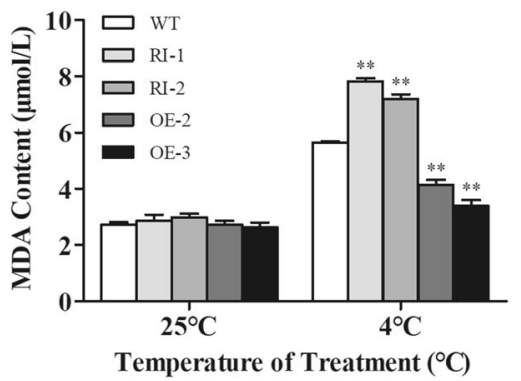

C

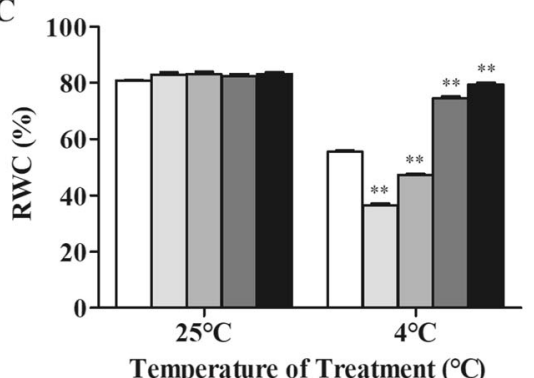

$\mathbf{E}$

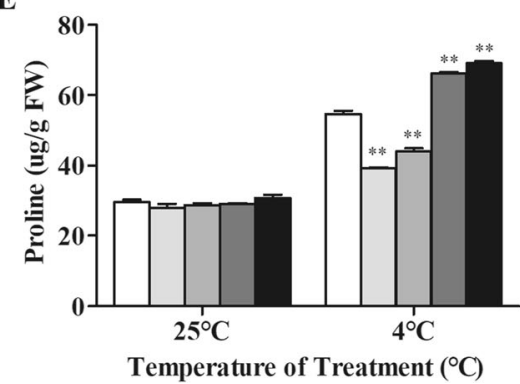

B

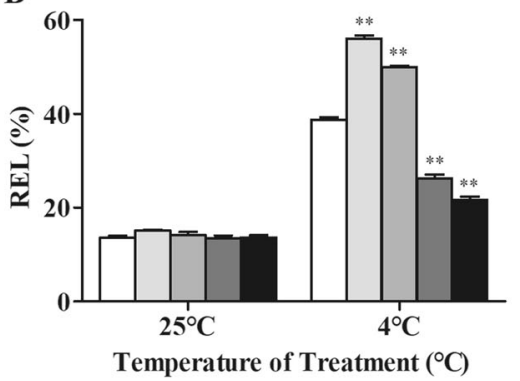

D
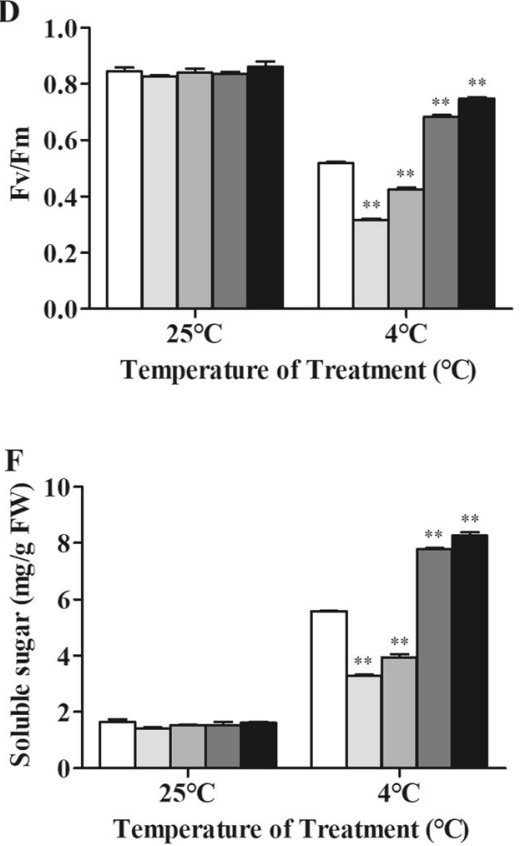

Fig. 8 Changes in WT and transgenic plant responses to cold stress in 6-week-old plants. a MDA contents. b REL. c RWC. d F $/ F_{m}$ values. e Proline contents. f Solute sugar levels. Uniformly sized 6-week-old tomato plants were subjected to a 5-day cold stress exposure at $4{ }^{\circ} \mathrm{C}$. Leaves that were the second and third from the top were assessed. Data are the means and SDs from triplicate samples. ${ }^{*} \mathrm{P}<0.05$ and ${ }^{* *} \mathrm{P}<0.01$

RNA-interference plants were elevated compared with wild-type controls. However, wild-type plants exhibited markedly elevated MDA and REL levels relative to LeGPA1-overexpressing transgenic plants $(P<0.01)$.

The relative water content (RWC) of plants reflects their water retention capacity and is used as a measure of plant water status and osmotic regulation. The RWCs of the transgenic and wild-type leaves were comparable to those before low-temperature stress (Fig. 8c). In contrast, the RWCs of both plant types decreased after stress, but the decline in the RWC of wild-type controls was significantly greater relative to that of the LeGPA1overexpressing transgenic plants $(P<0.01)$. The RWC values of the RNA-interference plants were markedly higher when compared with the wild-type controls $(\mathrm{P}<$ 0.01 ).
The maximum photochemical efficiency of photosystem II (PSII) was calculated as $\mathrm{Fv} / \mathrm{Fm}$. Under normal conditions, we detected no significant differences in photochemical efficiency when comparing the wild-type and transgenic plants (Fig. 8d). However, at low temperatures, the photochemical efficiencies of the wild-type and transgenic lines differed significantly $(\mathrm{P}<0.01)$. In all plants, the value steadily declined, but the decline was greater in magnitude in the wild-type plants relative to that of the LeGPA1-overexpressing transgenic plants, and still greater in magnitude in the RNA-interference lines.

Under low-temperature stress (vs. normal ambient growth temperature), all plants had increased soluble sugar and proline contents. Compared with wild-type plants, the LeGPA1-overexpressing transgenic plants had higher levels of soluble sugar and proline, and the RNA-interference 
transgenic plants had lower soluble sugar and proline levels (Fig. 8e, f). These findings suggest that the overexpression of LeGPA1 in processing tomato plants protects against the damage caused by low-temperature stress.

\section{Overexpression of LeGPA1 alleviates the accumulation of ROS in response to low-temperature stress}

Before applying a low-temperature treatment, the $\mathrm{H}_{2} \mathrm{O}_{2}$ and $\mathrm{O}_{2-}$ contents were low and almost identical in the wild-type and transgenic plants (Fig. 9). However, the ROS levels in all tested plants increased after exposure to low-temperature stress. Compared with wildtype plants, this increase was significantly greater in the RNAi plants and less in the LeGPA1-overexpressing plants. We found that overexpression of LeGPA1 reduced the accumulation of $\mathrm{H}_{2} \mathrm{O}_{2}$ and $\mathrm{O}_{2}{ }^{-}$under low-temperature stress.

To study the effects of overexpression and silencing of LeGPA1 on low-temperature stress-related oxygen scavenging, superoxide dismutase (SOD), peroxidase (POD), and catalase (CAT) enzyme activities were measured in wild-type and transgenic plants. We found that following low-temperature exposure, these three activities increased in all plants. However, relative to wild-type plants, there were significantly higher CAT, POD, and SOD activities in the LeGPA1-overexpressing transgenic plants $(P<0.01)$. The SOD, CAT, and POD activities in wild-type plants were significantly higher than those in RNA-interference plants (Fig. 10a-c). We found that overexpression of the LeGPA1 gene increased the activity of oxygen scavenging enzymes under lowtemperature stress, improving the plant's ROS scavenging ability and reducing ROS toxicity. This suggests that transgenic tomato plants can degrade more ROS. To determine the cause of the high CAT, SOD, and POD activities in transgenic tomato plants, we measured the $L e S O D, L e P O D$, and $L e C A T$ transcript levels. In standard growth conditions, the LeSOD, LePOD, and LeCAT expression levels were similar in all lines. Following low-temperature exposure, we recorded the upregulation of $L e S O D$, $L e P O D$, and $L e C A T$ in all plants, and the expression levels in the LeGPA1-overexpressing lines were higher compared with wild-type lines. However, the levels in the RNA-interference transgenic tomatoes were low (Fig. 10e-f). Therefore, we conclude that the high levels of LeSOD, LePOD, and LeCAT expression increased the corresponding enzyme activity and cleared more $\mathrm{H}_{2} \mathrm{O}_{2}$ and $\mathrm{O}_{2}{ }^{-}$ROS in the LeGPA1overexpressing transgenic tomatoes.

\section{LeGPA1 has a positive regulatory effect on cold-response} gene expression in processing tomatoes

We determined the expression levels of the INDUCER OF CBF EXPRESSION (ICE) and C-REPEAT-BINDING FACTOR (CBF) encoding genes (LeICE1 and LeCBF1) and their downstream target genes (LeTPS1, LeCOR413PM2, and LeDRCi7) in processing tomato lines. We found that before low-temperature stress, the RNAi lines exhibited reduced gene expression compared with wild-type plants, and the differences in the expression levels of LeCOR413PM2 and LeDRCi7 were highly significant. However, the expression levels of the genes were significantly lower in the wild-type than in the overexpressed lines. Following low-temperature stress, the gene expression levels of all plants showed an overall increasing trend; however, the difference in expression between wild-type and LeGPA1-overexpressing lines further increased and showed extremely significant differences (Fig. 11).

\section{Methods}

\section{Plants}

Wild-type L. esculentum ('Yaxin 87-5') seeds were obtained from Yaxin Seed Co. Ltd. (Shihezi City, Xinjiang, China). Plants were first grown in a $25^{\circ} \mathrm{C}$ tissue culture room $(16 / 8 \mathrm{~h}$ light/dark cycle) at $60-70 \%$ relative humidity and $200 \mu \mathrm{mol} \mathrm{m}^{-2} \mathrm{~s}^{-1}$ light intensity. Seedlings were next transplanted to pots that contained an equal mixture of soil, peat, and vermiculite, and were transferred to a $22-28^{\circ} \mathrm{C}$ greenhouse with natural lighting and identical humidity and light cycle conditions. While
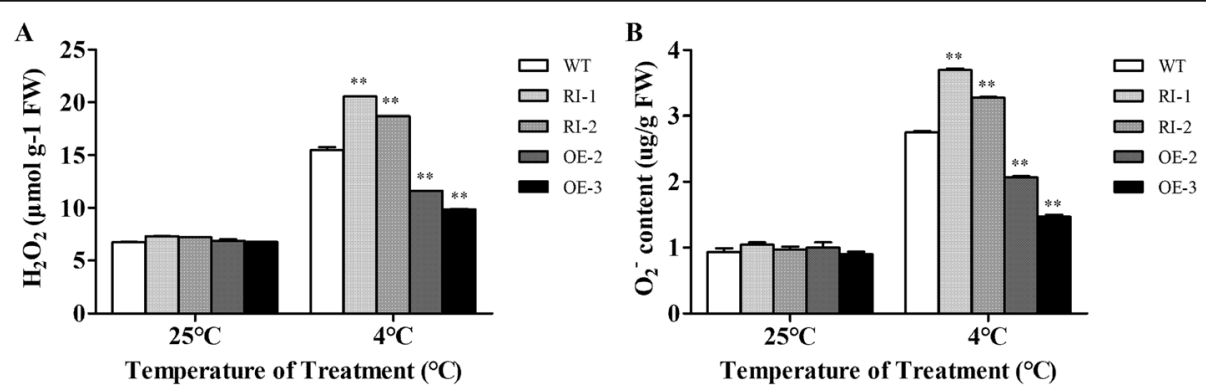

Fig. $9 \mathrm{ROS}\left(\mathrm{H}_{2} \mathrm{O}_{2}\right.$ and $\left.\mathrm{O}_{2}^{-}\right)$accumulation in WT and transgenic tomato plants exposed to cold stress. $\mathbf{a} \mathrm{H}_{2} \mathrm{O}_{2}$ levels. b $\mathrm{O}_{2}{ }^{-}$content. Uniformly sized 6-week-old tomato plants were subjected to a 5-day cold stress exposure at $4^{\circ} \mathrm{C}$. Leaves that were the second and third from the top were assessed. Data are the means and SDs from triplicate samples. ${ }^{*} \mathrm{P}<0.05$ and ${ }^{* *} \mathrm{P}<0.01$ 
A

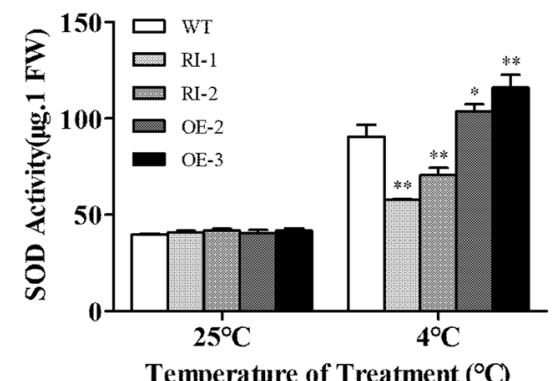

C

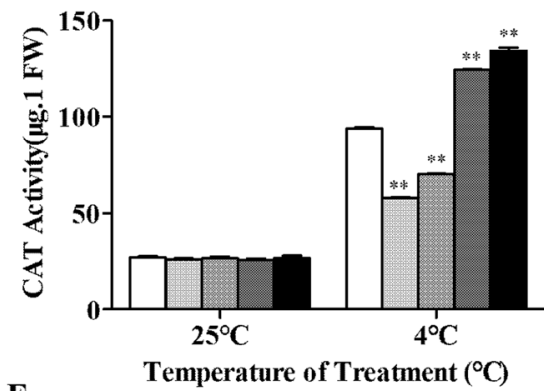

$\mathbf{E}$

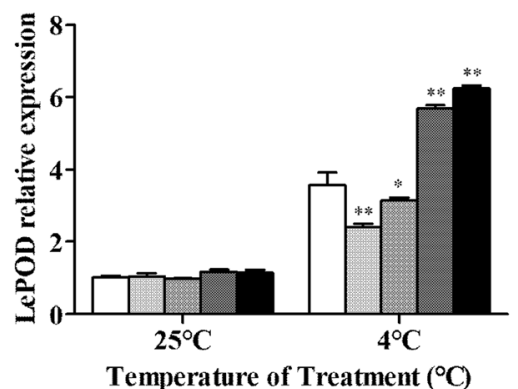

B

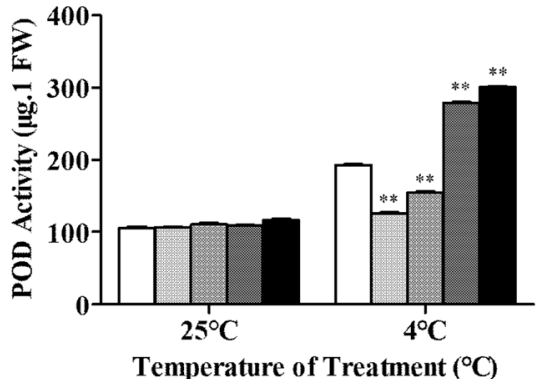

D
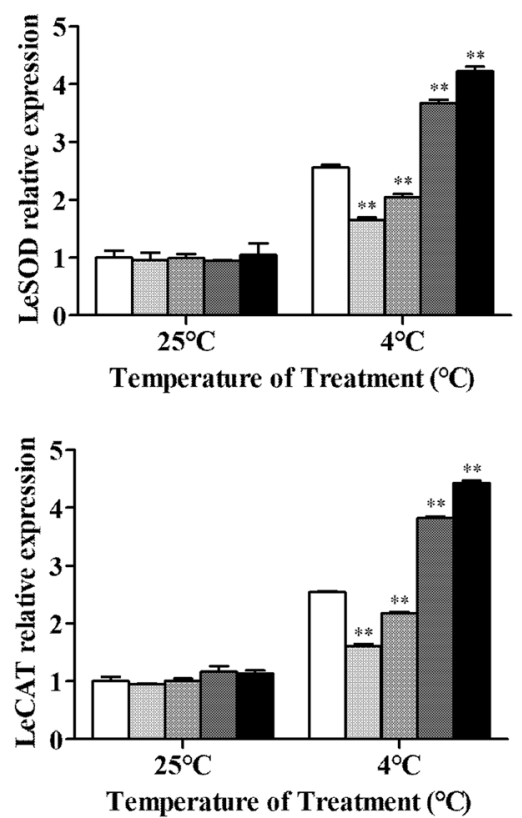

Fig. 10 Antioxidant enzyme (SOD, POD, and CAT) activity and expression of ROS-scavenging genes in WT and transgenic tomato plants exposed to cold stress. a SOD activity. b POD activity. c CAT activity. $\mathbf{d}$ Expression level of LeSOD. e Expression level of LePOD. $\mathbf{f}$ Expression level of LeCAT. Uniformly sized 6-week-old tomato plants were subjected to a 5-day cold stress exposure at $4^{\circ} \mathrm{C}$. Leaves that were the second and third from the top were assessed. Data are the means and SDs from triplicate samples. ${ }^{* P}<0.05$ and ${ }^{* *} P 0.01$

in this greenhouse, plants were irrigated with $500 \mathrm{~mL}$ of Hoagland's nutrient solution two times each week.

\section{Assessment of the impact of stress on LeGPA1 gene expression}

Seeds of wild-type tomato were sown in plastic pots. Then, the seedlings were grown under 14-h light/10-h dark photoperiod at $25 \pm 3{ }^{\circ} \mathrm{C}$ temperature and $60-70 \%$ relative humidity in a controlled greenhouse. By qRTPCR, we assessed LeGPA1 gene expression in a range of organs (fruit, flowers, stems, leaves, and roots) from 80day-old wild-type tomato plants. Also, LeGPA1 expression was assessed in wild-type tomatoes under cold, salt, or drought stress, carried out under the same conditions as above. All the stress treatments were performed using potted plants at the stage of 6-7 fully expanded leaves, 6-weeks-old, wild-type tomatoes seedlings selected based on their uniformity. For cold stress, wild-type tomato seedlings were well watered and then randomly placed in a cold chamber at $4{ }^{\circ} \mathrm{C}$ for $48 \mathrm{~h}$; control seedlings were placed under the same conditions but at $25^{\circ} \mathrm{C}$. For drought conditions, wild-type tomato seedlings were removed from the soil and then divided into two groups: the drought treatment group and the control group. The roots of seedlings in the drought treatment group were submerged 5-cm deep in 20\% PEG 6000 for $48 \mathrm{~h}$. The roots of the control group seedlings were submerged 5$\mathrm{cm}$ deep in water for $48 \mathrm{~h}$. Salt stress was induced by removing wild-type tomato seedlings from their soil and immersing the roots in $200 \mathrm{mM} \mathrm{NaCl}$ for $48 \mathrm{~h}$. The control group seedlings roots were submerged in water for $48 \mathrm{~h}$. Leaves from identical positions on these plants were collected at $0,1,3,6,9,12,24$, and $48 \mathrm{~h}$ after the initiation of stress conditions. Plants were grown in three separate growth chambers for replicate samples. Collected leaves were snap-frozen before storage at $-80^{\circ} \mathrm{C}$. 
A

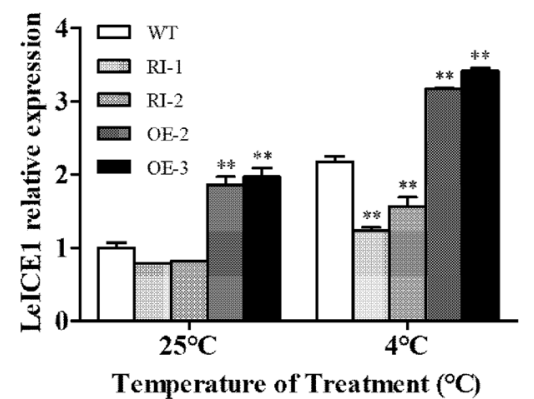

C

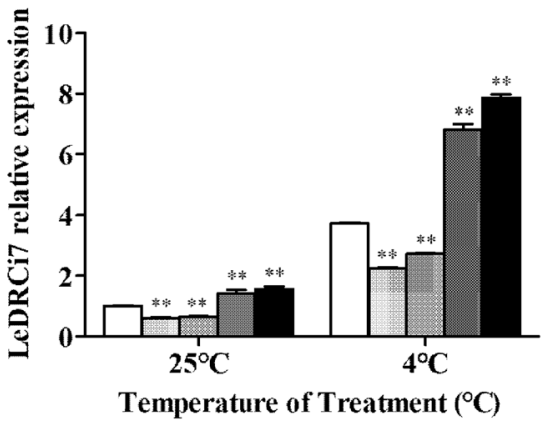

E

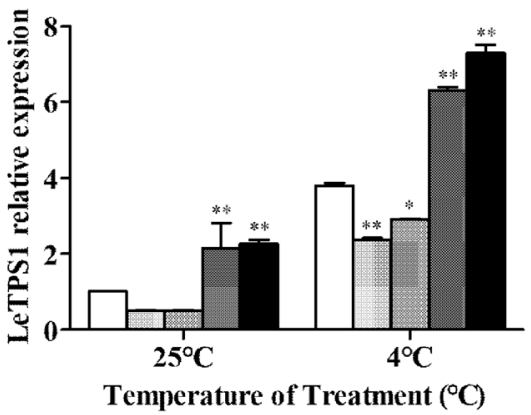

B

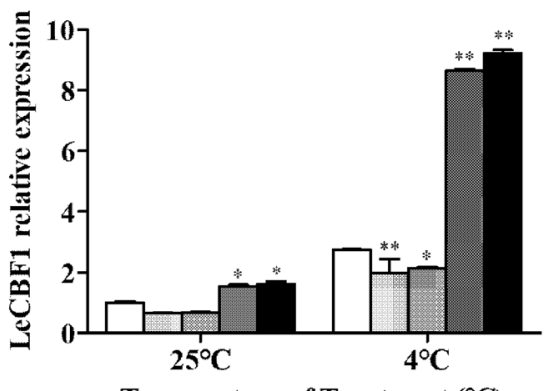

D

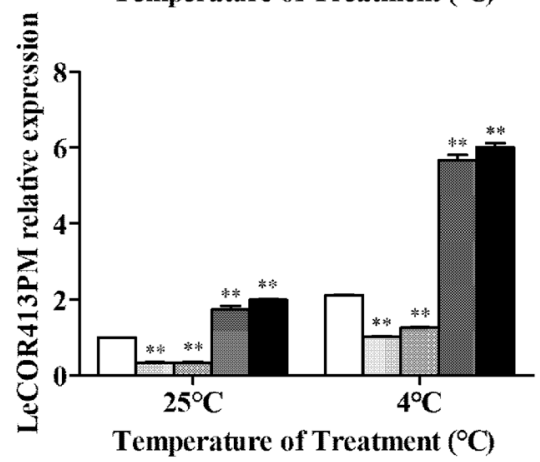

Fig. 11 Relative expression of stress-related genes in WT and transgenic tomato plants exposed to cold stress. a Expression level of LelCE1. b Expression level of LeCBF1. c Expression level of LeDRCi7. d Expression level of LeCOR413PM. e Expression level of LeTPS1. Total RNA was extracted from untreated and cold-treated $\left(4^{\circ} \mathrm{C}\right) 6$-week-old WT and transgenic tomato plants. The expression levels of stress-related genes were analyzed by qRT-PCR. Data are the means of three replicate samples. Bars represent SDs. ${ }^{*} \mathrm{P}<0.05$ and ${ }^{* *} \mathrm{P}<0.01$

An RNAprep Pure Plant Kit (Tiangen, China) was used to isolate sample RNA for qRT-PCR, after which cDNA was synthesized and analyzed with SYBR Green I Master Mix using a LightCycler 480II platform (Roche Biochemicals, Indianapolis, IN, USA). As a normalization control for cold stress-related gene expression, the tomato EF1 gene (GenBank ID: X53043) was utilized [37]. Thermocycler settings were: two cycles of $95^{\circ} \mathrm{C}$ for $30 \mathrm{~s} ; 50$ cycles of $95^{\circ} \mathrm{C}$ for $5 \mathrm{~s}, 60^{\circ} \mathrm{C}$ for $10 \mathrm{~s}$, and $68^{\circ} \mathrm{C}$ for $10 \mathrm{~s}$. The $2^{-\Delta \Delta \mathrm{Ct}}$ method [38] was used to measure the relative gene expression in stress treated plants compared with control plants. The primers used for this assay are shown in Supplementary Table S1. Three biological and technical replicates have been used during real-time PCR analysis. To ensure that a single discrete species was amplified, a melt curve analysis was performed at the end of the real-time PCR.

\section{LeGPA1 sequence assessment}

DNAMAN (v8.0) was used to align the LeGPA1 sequence. The TMHMM algorithm (http://www.cbs.dtu. $\mathrm{dk} /$ services/TMHMM/) was used for predicting transmembrane domains. MEGA 5.1 (http://www.megasoftware.net/) was used for phylogenetic analyses based on a Neighbor-Joining approach, and 1000 bootstrap replicates, with the deletion of bootstrap scores of $<50 \%$.

\section{LeGPA1 cloning}

An RNAisoPlus kit (TaKaRa, Dalian, China) was used to extract RNA from the leaves of tomato plants, with 
DNase I on-column digestion being conducted based on provided instructions. PrimeScript RTase (TaKaRa, Dalian, China) was used for first-strand cDNA synthesis, after which PCR was used to amplify full-length LeGPA1 using the LeGPA1 (Kpn I)-CF and LeGPA1 (Sal I)-CR (Table 1) primers designed using Solanum lycopersicum gene sequences (GenBank ID: NM 001306055.1). PrimeSTAR Max DNA polymerase (TaKaRa, Dalian, China) was used for PCR, with the following thermocycler settings: $95^{\circ} \mathrm{C}$ for $5 \mathrm{~min} ; 35 \mathrm{cy}$ cles of $95^{\circ} \mathrm{C}$ for $30 \mathrm{~s}, 56^{\circ} \mathrm{C}$ for $30 \mathrm{~s} ; 72^{\circ} \mathrm{C}$ for $10 \mathrm{~min}$. This approach yielded a 1176-bp PCR fragment, which was then cloned into the pMD19-T vector (TaKaRa, Dalian, China). The identity of this fragment was confirmed via DNA sequencing.

\section{Plasmid construction for overexpression and RNA interference (RNAi)}

PCR-amplified fragment of LeGPA1 was cloned into pCAMBIA2300 with KpnI and SalI restriction sites for LeGPA1 overexpression, for which the transcription of LeGPA1 was driven by the $35 \mathrm{~S}$ promoter. The RNAi construct was built by inserting a PCR-generated 220-bp segment of LeGPA1 cDNA (segment 340-560 bp) (the RNAi target) into pGM-T plasmid, followed by transformation into E. coli DH5 $\alpha$. The correct positive clone was named pGM-S (Supplemental Table S1). This pGM-S construct was then restriction enzyme digested (XhoI and $B g l \mathrm{II}$ ), and the smaller fragment was recovered and ligated with linearized (XhoI and BglII digested) pUCCRNAi. The recombinant pUCS1 vector was collected from E. coli DH5 $\alpha$ transformed with the ligated product. The pGM-S was then digested by restriction enzymes (XhoI and $B g l \mathrm{II})$ for subsequent small fragment recovery. The pUCS1 was digested by restriction enzymes (SalI and BamHI) for subsequent large fragment recovery. A reverse repeat sequence of the intermediate vector pUCS1S2 was generated by using pUCCRNAi intron. Then, pUCS1S2 was digested with PstI, followed by recovering the small fragments and cloning it into a linearized pCAM2300 vector (digested by PstI). Similarly, a reverse repeat sequence of the plant RNAi expression vector pCAS was also obtained. Finally, the pCAS was transferred into Agrobacterium GV3101 through freeze-thawing.

\section{Analyses of the subcellular localization of LeGPA1}

The complete open reading frame (ORF) of LeGPA1 excluding the stop codon was PCR-amplified with the primers containing $\mathrm{Xba \textrm {I }}$ and $\mathrm{BamH \textrm {I }}$ restriction site sequences, listed in Table 1. The p35S-LeGPA1-GFP was generated by cloning the amplicon into pCAMBIA2300GFP vector, followed by transducing into Arabidopsis mesophyll protoplasts using polyethylene glycol.
Similarly, to examine the plasma membrane localization, the PM-rk plasmid was transduced following the same approach [39-41]. The protoplasts were cultured at $23^{\circ} \mathrm{C}$ for $16 \mathrm{~h}$, and then a confocal microscopy (Leica Microsystems, Germany) was used to visualize the fluorescence at 488, 561, and $633 \mathrm{~nm}$ excitation wavelengths.

\section{Transgenic plant preparation}

Transgenic plants that overexpressed either LeGPA1 or an RNAi construct were prepared for this study. Briefly, under aseptic conditions, wild-type tomato seeds were evenly spread on $1 / 2$-MS medium, and tomato seedlings were gathered after about $10 \mathrm{~d}$ of culture. The cotyledon was cut off at both ends, and about $0.5 \mathrm{~cm}$ of the hypocotyl was cut, and placed on a differentiation medium for dark culture for $2 \mathrm{~d}$. The appropriate constructs were transformed into these hypocotyls using Agrobacterium tumefaciens strain GV3101. We then utilized $1 / 2$-strength MS medium supplemented with $60 \mathrm{mg} / \mathrm{L}$ kanamycin to screen for transgenic plants. After $\sim 20 \mathrm{~d}$, the callus grew from the explant, and was left for 2 months to sprout, then separated from the explant and inserted into rooting medium. After rooting, the cultivated seedlings were transplanted into pots containing nutrient soil for $7 \mathrm{~d}$, and then to the field when adaptability was strong. Isolated kanamycin-resistant $T_{0}$ plants were evaluated via semi-quantitative reverse transcription $\mathrm{PCR}$ using LeGPA1 primers (Supplementary Table S1), and qRTPCR was then used to confirm the identities of different transgenic plants. Plants in the $\mathrm{T}_{2}$-generation that retained their ability to grow on MS media supplemented with $60 \mathrm{mg} / \mathrm{L}$ kanamycin were utilized as transgenic plants in downstream assays.

Assessment of stress response-induced changes in plants Plants (wild-type or transgenic) from the $T_{2}$-generation were grown for $3-6$ weeks in a $25^{\circ} \mathrm{C}$ incubation chamber (16/8 h light/dark cycle; $70 \%$ humidity; $200 \mu \mathrm{mol} \mathrm{m}^{-2} \mathrm{~s}^{-1}$ photon flux density). After either 3 or 6 weeks, plants with uniform sizes were subjected to 5-day cold stress exposure $\left(4{ }^{\circ} \mathrm{C}\right)$. Plants were grown in three separate growth chambers for replicate samples. Changes in plant phenotypes were then visually assessed, and images were taken using a Canon 80D camera. The second and third leaves from the tops of each of these plants were additionally collected, and stress response-related and antioxidant enzyme gene expression in these leaves was assessed using qRT-PCR. These samples were also used for antioxidant activity assays and assessments of plant physiology.

\section{Physiological parameter analyses}

Relative water content (RWC) was assessed as described in a study conducted by Lara et al. [42] as follows: $\mathrm{RWC}=(\mathrm{FW}-\mathrm{DW}) /(\mathrm{TW}-\mathrm{DW}) \times 100 \%$. In this 
equation, FW corresponds to leaf fresh weight, TW corresponds to turgid weight (after leaves being incubated in $\mathrm{dH}_{2} \mathrm{O}$ for $24 \mathrm{~h}$ in the presence of light), and DW corresponds to dry weight (after leaves were dried at $70{ }^{\circ} \mathrm{C}$ to a constant weight).

The levels of MDA were assessed using thiobarbituric acid reaction following $\mathrm{Du}$ et al. [43] with modifications: The excised leaves were pre-rinsed with $\mathrm{dH}_{2} \mathrm{O}$, and the collected discs were used for the measurement of MDA level by using a spectrophotometer (UV-160A; Shimadzu Scientific Instruments, Japan).

Relative electrolyte leakage (REL) was evaluated using a conductivity meter (EC 215; Markson Science Inc., CA, USA) [43] by REL $=(\mathrm{C} 1-\mathrm{CW}) /(\mathrm{C} 2-\mathrm{CW}) \times 100$, in which formula the $\mathrm{C} 1$ and $\mathrm{C} 2$ correspond to pre- and post-boiled conductivity, respectively, and the CW corresponds to $\mathrm{dH}_{2} \mathrm{O}$ conductivity.

The maximal efficiency of photosystem II (PSII) was assessed using a portable fluorescence analyzer (DUALPAM-100; Walz, Germany). The leaves were pre-processed by $30 \mathrm{~min}$ placing at dark, followed by $1 \mathrm{~s}$ flash light exposure. Variable fluorescence $\left(F_{v}\right)$ was evaluated by $F_{v}=F_{m}-F_{0}$ [44], in which formula the $\mathrm{F}_{0}$ (minimal fluorescence) corresponds to the dark-adapted state with all the centers of PSII reaction opened; the $\mathrm{F}_{\mathrm{m}}$ (maximal fluorescence) corresponds to the light-saturated state with all the centers of PSII reaction closed.

Free proline was assessed as in the study of Bates et al. [45]. Briefly, $4 \mathrm{~mL}$ of $3 \%$ sulfosalicylic acid was used to extract leaf samples $(200 \mathrm{mg})$ for $10 \mathrm{~min}$ at $100^{\circ} \mathrm{C}$, after which homogenates were spun for $2 \mathrm{~min}$ at $12,000 \times \mathrm{g}$. Next, a 2 $\mathrm{mL}$ supernatant volume was mixed with equivalent volumes of acid-ninhydrin reagent and glacial acetic acid. This solution was then boiled for $30 \mathrm{~min}$, before being transferred into an ice bath. Absorbance at $520 \mathrm{~nm}$ was then assessed following toluene $(4 \mathrm{~mL})$-mediated extraction of the organic phase. Proline concentrations were determined relative to a proline standard curve.

The Anthrone method was used for analyses of soluble sugars, using glucose as a standard [46]. Briefly, an initial leaf

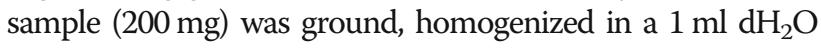
volume, boiled for $20 \mathrm{~min}$, centrifuged for $10 \mathrm{~min}$ at 13 , $000 \times g$, and a $2-\mathrm{mL}$ supernatant volume was then combined with $1.8 \mathrm{~mL} \mathrm{dH}_{2} \mathrm{O}$ and $2.0 \mathrm{~mL}$ of $0.14 \%$ (w/v) Anthrone solution in $100 \% \mathrm{H}_{2} \mathrm{SO}_{4}$. This solution was rested for $20 \mathrm{~min}$ in boiling water, after which it was cooled, and the $\mathrm{A}_{620}$ was assessed. Total soluble sugar levels were assessed by comparing these $\mathrm{A}_{620}$ values with those derived from a glucose standard curve. Experiments were conducted in triplicate using three replicate samples.

\section{ROS and antioxidant activity assays}

Approximately $0.5 \mathrm{~g}$ fresh leaves were collected from the transgenic $\left(\mathrm{T}_{2}\right)$ or wild-type plants for exposure to stress. The minced leaf samples were homogenized in 4 $\mathrm{ml}$ of $50 \mathrm{mM}$ sodium phosphate buffer ( $\mathrm{pH} 7.8$ ) supplemented with $10 \mathrm{mM} \beta$-ME and $1 \%$ polyvinylpyrrolidone, followed by centrifuging for $15 \mathrm{~min}$ at $4{ }^{\circ} \mathrm{C}$ and 17 , $426 \times \mathrm{g}$. The activities of CAT and SOD were measured following previously described methods $[47,48]$, respectively. The activity of POD was assessed using a microplate reader (Infinite M200 Pro; Tecan Group Ltd., Männedorf, Switzerland) [49].

The levels of $\mathrm{H}_{2} \mathrm{O}_{2}$ and $\mathrm{O}_{2}{ }^{-}$were also evaluated by measuring the absorbance using the above-mentioned UV-160A spectrophotometer (Shimadzu Scientific Instruments, Japan) [50].

\section{Statistical analysis}

Data were assessed using SPSS v13.0 and GraphPad Prism 7.0. Relative LeGPA1 expression data are presented as mean \pm standard deviation from triplicate samples, with three leaves per seedling being used as a replicate. Expression levels were normalized to baseline $(0 \mathrm{~h})$ levels. Dunnett's multiple comparison test was used to compare plants. ${ }^{*} P<0.05$ and ${ }^{* *} P<0.01$ correspond to significant and very significant, respectively.

\section{Discussion}

The Go subunit is an important component of the heterotrimer G-protein complex; it not only plays important roles in various plant growth and development processes but also participates in responses to abiotic stresses, such as drought and high and low temperatures $[35,51,52]$. The Go subunit has been well studied in model plants, but it had not been previously identified in processing tomatoes. In this study, we identified a Gprotein $G \alpha$ subunit from processing tomatoes and studied its growth and development, as well as the resistance to low temperature it provides.

We found the LeGPA1 gene of processing tomatoes is homologous with the GPA1 gene of other nightshade species. Previous studies have found that GPA1 is only expressed in mature seeds [53], and GPA1 expression has been detected in all stages of development and all organs. GPA1 expression is highest in the roots, followed by the stem tip, hypocotyl, cotyledon, and leaf [54], and levels are higher in immature than mature organs [53]. We analyzed the expression of LeGPA1 in various organs of processing tomato plants and found that LeGPA1 was expressed in all organs tested (relative expression abundance: roots $>$ leaves $>$ fruits $>$ stems). Such an expression pattern suggests that LeGPA1 is involved in the regulation of the growth and development of processing tomatoes. We also performed a subcellular localization experiment and found that LeGPA1 is also localized in the cell membrane. This is consistent with the literature on G-proteins in plants [55-57]. 
The G-protein G $\alpha$ subunit has been identified in Arabidopsis, rice, and maize, and acts as a positive regulator of cell proliferation and growth in all three species [21, $58,59]$. Through the functional analysis of the G-protein $\alpha$ subunit GPA1 in cucumber, Yan et al. found that overexpression of CsGPA1 promoted seed germination and early seedling growth, while CsGPA1 interference inhibited seedling growth. By testing the biological characteristics of transgenic lines and wild-type processing tomato plants [60], here we found that LeGPA1-overexpressing tomato plants were significantly taller than the wild-type plants, whereas the RNA interference plants were shorter. This indicates that LeGPA1 plays an important role in the regulation of processing tomato plant height, which is consistent with what has been described for Arabidopsis, rice, and maize.

The G-protein $\alpha$ subunits also play important roles in the signal transduction pathway of abiotic stress in plants [26]. The full transcriptome microarray analysis of rice revealed that rice $R G A 1$ could regulate low temperature, salt, and drought stress and transmit stress signals to the small phosphorylase GTPase and corresponding effector proteins or molecules, such as ion channels [28]. In pea, expression of the PsGPA1 gene was significantly altered by $\mathrm{NaCl}$ and high temperature [29]. A study of Brassica napus found that the expression of $B n G A 1$ was induced by four abiotic stresses [20\% PEG6000, $200 \mathrm{~mm} \mathrm{NaCl}$, low temperature $\left(4{ }^{\circ} \mathrm{C}\right)$, and high temperature $\left.\left(40^{\circ} \mathrm{C}\right)\right]$ and that $B n G A 1$ plays an important role in resisting abiotic stress [54]. Consistent with the cited literature, here we report that in processing tomato, LeGPA1 is induced by drought, high salt, and low temperature.

GPA1 in Arabidopsis is involved in oxidative stress signal transduction. For example, GPA1 can positively regulate abiotic stress factors upstream of ROS production [27]. ROS are produced and accumulate under cold stress; they destroy cells and produce MDA [61, 62]. Antioxidant enzymes are an important part of the ROS scavenging system in plant cells and, therefore, play important roles in plant cold resistance [63, 64]. For example, Pinus koraiensis is an evergreen tree species with strong cold resistance. A large number of DEGs were identified in $P$. koraiensis under cold stress, especially the DEGs removing ROS in antioxidation mechanisms [65]. Antioxidant enzyme activities in plants have been reported to increase under low-temperature stress, which might be due to the upregulation of corresponding genes $[60,66,67]$. In line with the literature, here we report that the expression of LeGPA1 in processing tomatoes is upregulated under low-temperature stress. Moreover, overexpression of LeGPA1 in a transgenic tomato line improved the antioxidant capacity and decreases membrane lipid peroxidation under low-temperature stress, indicating that
LeGPA1 positively regulates the response of processing tomatoes to low temperature.

Multiple genes have been implicated in plant response to low-temperature stress, including ICE1-activation of the CBF pathway [68-71], trehalose 6-phosphatase (TPS) (a key enzyme in trehalose synthesis) and TPSrelated genes [72, 73], and the Arabidopsis cold resistance gene 413 (AtCOR413) (important for frost resistance) [74]. An ICE-CBF-COR signaling pathway activates the appropriate expression of downstream genes, which encode osmoregulation substances [75]. This study analyzed the expression levels of genes related to low-temperature stress in processing tomatoes. LeGPA1 increased LeICE1 gene expression in processing tomatoes, thereby regulating the transcription of the $L e C B F 1$ gene. Thus, the expression of LeCOR413PM2 and LeTPS1 and its downstream regulatory gene, $L e D R C i 7$, was induced. These findings identify the molecular mechanisms likely involved LeGPA1-mediated low-temperature tolerance in processing tomato. However, the molecular mechanisms that regulate LeGPA1 activation and inactivation, as well as the downstream effector cycling, are still unknown. Therefore, to elucidate how plant $G$ proteins interact with environmental signals to maintain stable growth and development in a varied environment, in the future, molecular biological technologies (e.g., immunoco-precipitation and bilateral fluorescence complementary) should be further utilized to verify, isolate, and identify the proteins interacting with LeGPA1, and determine the downstream effector molecules and signal transduction mechanism of LeGPA1.

\section{Conclusion}

Together, these findings suggest that LeGPA1 overexpression is a viable approach to improving resistance to cold stress in tomato. We found that LeGPA1 overexpression is associated with increased cell membrane integrity and stability in response to cold stress, while also reducing the accumulation of membrane lipid peroxidation products, decreasing the ion leakage rates, and increasing antioxidant enzyme activity. These changes were associated with improved photochemical electron transport efficiency and antioxidant enzyme activity. For example, the LeGPA1overexpressing plants exhibited reduced ROS levels compared with the wild-type controls. Low-temperature tolerance was improved in these plants via the maintenance of elevated permeable proline and soluble sugar levels to protect against cellular damage.

\section{Supplementary information}

Supplementary information accompanies this paper at https://doi.org/10. 1186/s12870-020-02615-w.

Additional file 1: Figure S1. The acquirements of LeGPA1-OE and LeGPA1-RNAi lines. Figure S2. Semi-quantitative PCR was used to assess 
LeGPA1 transcript levels in leaves collected from plants grown under standard conditions. M: DL5000 DNA Marker, WT: Wild-type tomato plants, O1-O3: LeGPA1-overexpressing transgenic tomato plants, RI-R3: RNAi transgenic tomato plant lines. Supplementary Table S1. List of primers used in this study.

\section{Acknowledgements}

We would like to thank TopEdit (www.topeditsci.com) for the English language editing of this manuscript.

\section{Declarations}

The authors declare that they have no known competing financial interests or personal relationships that could have appeared to influence the work reported in this paper.

\section{Authors' contributions}

XYG and JJL Methodology, Data curation, Visualization. LZ Conceptualization, Writing- Original draft preparation. ZWZ Supervision. PH Software. WWW Validation. MW Investigation. AYW Design of the work. JBZ WritingReviewing and Editing. All Authors read and approved the manuscript.

\section{Funding}

This work was supported by the National Science Foundation Project (31360053), National GMO Major Project (2016ZX080005004-009), and Key scientific and technological projects for the cultivation of new varieties of genetically modified organisms (2018ZX0800501B-005).

\section{Availability of data and materials}

The datasets used and/or analysed during the current study are available from the corresponding author on reasonable request.

\section{Ethics approval and consent to participate}

Not applicable.

\section{Consent for publication}

Not applicable.

\section{Competing interests}

The authors declare that they have no competing interests.

Received: 10 April 2020 Accepted: 19 August 2020

Published online: 26 August 2020

\section{References}

1. Shabala S, Bose J, Fuglsang AT, Pottosin I. On a quest for stress tolerance genes: membrane transporters in sensing and adapting to hostile soils. J Exp Bot. 2015;67:1015-31..

2. Ji TH, Grossmann M, Ji I. G-protein coupled receptors. J Biol Chem. 1998;273: 1138.

3. Burg JS, Ingram JR, Venkatakrishnan AJ, Jude KM, Dukkipati A, Feinberg EN, Angelini A, Waghray D, Dror RO, Ploegh HL, Garcia KC. Structural basis for chemokine recognition and activation of a viral $\mathrm{G}$ protein-coupled receptor. Science. 2015;34:1113-7.

4. Wettschureck N, Offermanns S. Mammalian G proteins and their cell type specific functions. Physiol Rev. 2005;85:1159-204

5. Assmann SM. Heterotrimeric and unconventional GTP binding proteins in plant cell signaling. Plant Cell. 2002;14:355-73.

6. Ma H, Yanofsky MF, Meyerowitz EM. Molecular cloning and characterization of GPA1, a G protein alpha subunit gene from Arabidopsis thaliana. Proc Nati Acad Sci. 1990;87:3821-5.

7. Ma H. GTP-binding proteins in plants: new members of an old family. Plant Mol Biol. 1995;26:1611-36.

8. Ishikawa A, Tsubouchi H, Iwasaki Y, Asahi T. Molecular-cloning and characterization of a cDNA for the alpha-subunit of a G-protein from rice. Plant Cell Physiol. 1995:36:353-9.

9. Seo HS, Kim HY, Jeong JY, Lee SY, Bahk JD. Molecular cloning and characterization of RGA1 encoding a $\mathrm{G}$ protein a subunit from rice (Oryza sativa I. ir-36). Plant Mol Biol. 1995;27:1119-31.
10. Jones HD, Smith SJ, Desikan R, Plakidou-Dymock S, Hooley LR. Heterotrimeric $\mathrm{G}$ proteins are implicated in gibberellin induction of aamylase gene expression in wild Oat aleurone. Plant Cell. 1998;10:245-53.

11. Ma H, Yanofsky MF, Huang $\mathrm{H}$. Isolation and sequence analysis of TGA1 CDNAs encoding a tomato G protein a subunit. Gene. 1991;107:189-95.

12. Gotor C, Lam E, Cejudo FJ, Romero LC. Isolation and analysis of the soybean SGA2 gene (CDNA), encoding a new member of the plant G-protein family of signal transducers. Plant Mol Biol. 1996:32:1227-34.

13. Kim WY, Cheong NE, Lee DC, Je DY, Bahk JD, Cho MJ, et al. Cloning and sequencing analysis of a full-length CDNA encoding a $\mathrm{G}$ protein a subunit, SGA1, from soybean. Plant Physiol. 1995;108:1315-6.

14. Marsh JF III, Kaufman LS. Cloning and characterization of PGA1 and PGA2: two $\mathrm{G}$ protein a-subunits from pea that promote growth in the yeast Saccharomyces cerevisiae. Plant J. 1999;19:237-47.

15. Perroud PF, Diogon T, Crevecoeur M, Greppin H. Molecular cloning, spatial and temporal characterization of pinach SOGA1 CDNA, encoding an a subunit of G protein. Gene. 2000;248:191-201.

16. Kaydamov C, Tewes A, Adler K, Manteuffel R. Molecular characterization of CDNAs encoding $\mathrm{G}$ protein alpha and beta subunits and study of their temporal and spatial expression patterns in Nicotiana plumbaginifolia viv. Biochim Biophys Acta. 2000;1491:143-60.

17. Ullah $\mathrm{H}$, Chen JG, Wang S, Jones AM. Role of a heterotrimeric G protein in regulation of Arabidopsis seed germination. Plant Physiol. 2002;129:897-907.

18. Chen YL, Huang R, Xiao YM, Lü P, Chen J, Wang XC. Extracellular calmodulin-induced stomatal closure is mediated by heterotrimeric $\mathrm{G}$ protein and $\mathrm{H}_{2} \mathrm{O}_{2}$. Plant Physiol. 2004;136:4096-103.

19. Pandey S, Che JG, Jones AM, Assmann SM. G-protein complex mutants are hypersensitive to abscisic acid regulation of germination and postgermination development. Plant Physiol. 2006;141:243-56.

20. Ullah H, Chen JG, Temple B, Boyes DC, Alonso JM, Davis KR, et al. The $\beta$-subunit of the Arabidopsis $\mathrm{G}$-protein negatively regulates auxin-induced cell division and affects multiple developmental processes. Plant Cell. 2003:15:393-409.

21. Ullah $\mathrm{H}$, Chen JG, Young JC, Im KH, Sussman MR, Jones AM. Modulation of cell proliferation by heterotrimeric G-protein in Arabidopsis. Science. 2001:292:2066-9.

22. Jones AM, Ecker JR, Chen JG. A reevaluation of the role of the heterotrimeric $\mathrm{G}$ protein in coupling light responses in Arabidopsis. Plant Physiol. 2003;131:1623-7.

23. Ashikari M, Wu J, Yano M, Sasaki T, Yoshimura A. A rice gibberellininsensitive dwarf mutant gene dwarf 1 encodes the a-subunit of GTPbinding protein. Proc Nati Acad Sci USA. 1999:96:10284-9.

24. Fujisawa Y, Kato T, Ohki S, Ishikawa A, Kitano H, Sasaki T, et al. Suppression of the heterotrimeric $\mathrm{G}$ protein causes abnormal morphology, including dwarfism, in rice. Proc Nati Acad Sci. 1999;96:7575-80.

25. Oki K, Inaba N, Kitagawa K, Fujioka S, Iwasaki Y. Function of the subunit of rice heterotrimeric $\mathrm{G}$ protein in brassinosteroid signaling. Plant Cell Physiol. 2008;50:161-72.

26. Yadav DK, Shukla D, Tuteja N. Rice heterotrimeric g protein alpha subunit (RGA1): in silico analysis of the gene and promoter and its upregulation under abiotic stress. Plant Physiol Biochem. 2013:63:262-71.

27. Zhang W, Jeon BW, Assmann SM. Heterotrimeric G-protein regulation of ROS signalling and calcium currents in Arabidopsis guard cells. J Exp Bot. 2011;62:2371-9.

28. Jangam AP, Pathak RR, Raghuram N. Microarray analysis of rice d1 (RGA1) mutant reveals the potential role of $\mathrm{G}$-protein alpha subunit in regulating multiple abiotic stresses such as drought, salinity, heat, and cold. Front Plant Sci. 2016;7:11.

29. Misra S, Wu Y, Venkataraman G, Sopory SK, Tuteja N. Heterotrimeric Gprotein complex and G-protein-coupled receptor from a legume (Pisum sativum): role in salinity and heat stress and cross-talk with phospholipase c. Plant J. 2007:51:656-69.

30. Ferrero-Serrano A, Assmann SM. The a-subunit of the rice heterotrimeric $\mathrm{G}$ protein, $R G A 1$, regulates drought tolerance during the vegetative phase in the dwarf rice mutant d1. J Exp Bot. 2016;67:3433-43.

31. Chakraborty N, Sharma P, Kanyuka K, Pathak RR, Choudhury D, Hooley R, et al. G-protein a-subunit (GPA1) regulates stress, nitrate and phosphate response, flavonoid biosynthesis fruit/seed development and substantially shares GCR1 regulation in A. thaliana. Plant Mol Biol. 2015;89:559-76.

32. Chakraborty N, Singh N, Kaur K, Raghuram N. G-protein signaling components GCR1 and GPA1 mediate responses to multiple abiotic stresses in Arabidopsis. Front Plant Sci. 2015;6:1000.

33. Yadav DK, Islam SM, Tuteja N. Rice heterotrimeric g protein gamma subunits (RGG1 and RGG2) are differentially regulated under abiotic stress. Plant Signal Behav. 2012;7:733-40. 
34. Yadav DK, Shukla D, Tuteja N. Isolation, in silico characterization, localization and expression analysis of abiotic stress-responsive rice $\mathrm{G}$-protein $\beta$ subunit (RGB1). Plant Signal Behav. 2014;9:e28890.

35. Ma Y, Dai $X, X u Y$, Luo W, Zheng $X$, Zeng D, et al. Cold1 confers chilling tolerance in rice. Cell. 2015;6:1209-21.

36. Thompson PA. Characterisation of the germination responses to temperature of vegetable seeds. I. Tomatoes. Sci Hortic. 1974;2:35-54.

37. Lovdal T, Lillo C. Reference gene selection for quantitative real-time PCR normalization in tomato subjected to nitrogen, cold, and light stress. Anal Biochem. 2009;387:238-42.

38. Livak KJ, Schmittgen TD. Analysis of relative gene expression data using real-time quantitative PCR and the 2- $\Delta$ Ct method. Methods. 2001;25:402-8.

39. Nelson BK, Cai X, Nebenfuhr A. A multi-color set of in vivo organelle markers for colocalization studies in Arabidopsis and other plants. Plant J. 2007:51:1126-36.

40. Hu W, Yuan Q, Wang Y, Cai R, Deng X, Wang J, et al. Overexpression of a wheat aquaporin gene, $T a A Q P 8$, enhances salt stress tolerance in transgenic tobacco. Plant Cell Physiol. 2012;53:2127-41.

41. Zhou S, Hu W, Deng X, Ma Z, Chen L, Huang C, et al. Overexpression of the wheat aquaporin gene, TAAQP7, enhances drought tolerance in transgenic tobacco. PLoS One. 2012;7:e52439.

42. Lara MV, Disante KB, Podestá FE, Andreo CS, Drincovich MF. Induction of a crassulacean acid like metabolism in the $\mathrm{C}_{4}$ succulent plant, Portulaca oleracea L.: physiological and morphological changes are accompanied by specific modifications in phosphoenolpyruvate carboxylase. Photosynth Res. 2003;77:241-54

43. Du Z, Bramlage WJ. Modified thiobarbituric acid assay for measuring lipid oxidation in sugar-rich plant tissue extracts. J Agric Food Chem. 1992;40: 1566-70.

44. Krause GH, Weis E. Chlorophyll fluorescence and photosynthesis: the basics. Annu Rev Plant Physiol Mol Biol. 1991;42:313-49.

45. Bates LS, Waldren RP, Teare ID. Rapid determination of free proline for water-stress studies. Plant Soil. 1973;1:205-7.

46. Fukao T, Xu K, Ronald PC, Bailey-Serres J. A variable cluster of ethylene response factor-like genes regulates metabolic and developmental acclimation responses to submergence in rice. Plant Cell. 2006;18:2021-34.

47. Cakmak I, Marschner H. Magnesium deficiency and high light intensity enhance activities of superoxide dismutase, ascorbate peroxidase, and glutathione reductase in bean leaves. Plant Physiol. 1992;98:1222-7.

48. Beauchamp C, Fridovich I. Superoxide dismutase: improved assays and an assay applicable to acrylamide gels. Anal Biochem. 1971;44:276-87.

49. Doerge DR, Divi IL, Churchwell ML. Identification of the colored guaiacol oxidation product produced by peroxidases. Anal Biochem. 1997;250:10-7.

50. Benikhlef L, Haridon LF, Abou-Mansour E, Serrano M, Binda M, Costa A, et al Perception of soft mechanical stress in Arabidopsis leaves activates disease resistance. BMC Plant Biol. 2013;13:133.

51. Wang XQ, Ullah H, Jones AM, Assmann SM. G protein regulation of ion channels and abscisic acid signaling in Arabidopsis guard cells. Science. 2001;292:2070-2.

52. Coursol S, Fan LM, Le Stunff H, Spiegel S, Gilroy S, Assmann SM. Sphingolipid signalling in Arabidopsis guard cells involves heterotrimeric G proteins. Nature. 2003;423:651-4.

53. Catherine AW, Huang $\mathrm{H}, \mathrm{Ma} \mathrm{H}$. Immunolocalization of the $\mathrm{G}$ protein a subunit encoded by the GPA1 gene in Arabidopsis. Plant Cell. 1993;5:151328

54. Gao Y, Li T, Liu Y, Ren C, Zhao Y, Wang M. Isolation and characterization of gene encoding $G$ protein a subunit protein responsive to plant hormones and abiotic stresses in Brassica napus. Mol Biol Rep. 2010;37:3957-65.

55. Pandey S, Assmann SM. The Arabidopsis putative G protein-coupled receptor GCR1 interacts with the $\mathrm{G}$ protein a subunit GPA1 and regulates abscisic acid signaling. The Plant Cell Online. 2004;16:1616-32.

56. Zhang LY, Fang KF, Lin JX. Heterotrimeric G protein a-subunit is localized in the plasma membrane of Pinus bungeana pollen tubes. Plant Sci. 2005;169: 1066-73.

57. Chen $Y$, Ji FF, Xie H, Liang JS, Zhang JH. The regulator of $G$ protein signaling proteins involve in sugar and abscisic acid signaling in Arabidopsis seed germination. Plant Physiol. 2006;140:302-10.

58. Ueguchi-Tanaka M, Fujisawa Y, Kobayashi M, Ashikari M, Iwasaki Y, Kitano H, et al. Rice dwarf mutant $d 1$, which is defective in the alpha subunit of the heterotrimeric $\mathrm{G}$ protein, affects gibberellin signal transduction. Proc Nati Acad Sci. 2000;9:11638-43.
59. Bommert $\mathrm{P}$, Je Bl, Goldshmidt A, Jackson D. The maize Ga gene COMPACT PLANT 2 functions in CLAVATA signalling to control shoot meristem size. Nature. 2013;502:555-8.

60. Yan Y, Zhang W, Li Y, He C, Gao L, Yu X. Functions of CsGPA1 on the hypocotyl elongation and root growth of cucumbers. Sci Rep. 2018;8:15583.

61. Achard P, Gong F, Cheminant S, Alioua M, Hedden P, Genschik P. The coldinducible CBF1 factor-dependent signaling pathway modulates the accumulation of the growth-repressing della proteins via its effect on gibberellin metabolism. The Plant Cell Online. 2008;20:2117-29.

62. Swain DM, Sahoo RK, Srivastava VK, Tripathy BC, Tuteja R, Tuteja N. Function of heterotrimeric G-protein $\gamma$ subunit RGG1 in providing salinity stress tolerance in rice by elevating detoxification of ROS. Planta. 2016;245:367-83.

63. Ahmad P, Jaleel CA, Salem MA, Nabi G, Sharma S. Roles of enzymatic and nonenzymatic antioxidants in plants during abiotic stress. Crit Rev Biotechnol. 2010;30:161-75.

64. Liu L, Duan L, Zhang J, Zhang Z, Mi G, Ren H. Cucumber (Cucumis sativus L.) over-expressing cold-induced transcriptome regulator ICE1 exhibits changed morphological characters and enhances chilling tolerance. Sci Hortic. 2010;124:29-33.

65. Wang F, Chen S, Liang D, Qu GZ, Chen S, Zhao X. Transcriptomic analyses of Pinus koraiensis under different cold stresses. BMC Genomics. 2020;21:10.

66. Baek KH, Skinner DZ. Alteration of antioxidant enzyme gene expression during cold acclimation of near-isogenic wheat lines. Plant Sci. 2003;165: 1221-7.

67. Soltész A, Tímár I, Vashegyi I, Toth B, Kellos T, Szalai G, Vágújfalvi A, Kocsy G, Galiba G. Redox changes during cold acclimation affect freezing tolerance but not the vegetative/ reproductive transition of the shoot apex in wheat. Plant Biol. 2011;13:757-66.

68. Winfield MO, Lu C, Wilson ID, Coghill JA, Edwards KJ. Plant responses to cold: transcriptome analysis of wheat. Plant Biotechnol J. 2010;8:749-71.

69. Chinnusamy V, Zhu J, Zhu JK. Cold stress regulation of gene expression in plants. Trends in Plant Sci. 2007;12:444-51.

70. Zhu JK. Abiotic stress signaling and responses in plants. Cell. 2016;167:31324.

71. Miura K, Shiba H, Ohta M, Kang SW, Sato A, Yuasa T, et al. SIICE1 encoding a MYC-type transcription factor controls cold tolerance in tomato, Solanum lycopersicum. Plant Biotechnol. 2012;29:253-60.

72. Tomikubo Y, Yuasa T, Iwaya-Inoue M. Analysis of chilling-induced trehalose6-phosphate synthase (TPS) in tomato plants. Cryobiol Cryotechnol Japanese. 2007;53:95-100.

73. Nakamura J, Yuasa T, Huong TT, Harano K, Tanaka S, Iwata T, et al. Rice homologs of inducer of CBF expression (osice) are involved in cold acclimation. Plant Biotechnol. 2011;28:303-9.

74. Breton G, Danyluk J, Charron JB, Sarhan F. Expression profiling and bioinformatic analyses of a novel stress-regulated multi spanning transmembrane protein family from cereals and Arabidopsis. Plant Physiol. 2003;132:64-74.

75. Ritonga FN, Chen S. Physiological and molecular mechanism involved in cold stress tolerance in plants. Plants. 2020;9:560

\section{Publisher's Note}

Springer Nature remains neutral with regard to jurisdictional claims in published maps and institutional affiliations.

Ready to submit your research? Choose BMC and benefit from:

- fast, convenient online submission

- thorough peer review by experienced researchers in your field

- rapid publication on acceptance

- support for research data, including large and complex data types

- gold Open Access which fosters wider collaboration and increased citations

- maximum visibility for your research: over $100 \mathrm{M}$ website views per year

At $\mathrm{BMC}$, research is always in progress.

Learn more biomedcentral.com/submissions 